Article

\title{
A Framework for Sustainable Planning and Decision-Making on Resource Recovery from Wastewater: Showcase for São Paulo Megacity
}

\author{
Mariana C. Chrispim ${ }^{1,2}\left(\mathbb{D}\right.$, Fernanda de M. de Souza ${ }^{2}$, Miklas Scholz ${ }^{1,3,4, * \mathbb{D}}$ \\ and Marcelo A. Nolasco ${ }^{2}$ (D) \\ 1 Division of Water Resources Engineering, Faculty of Engineering, Lund University, John Ericssons väg 1, \\ P.O. Box 118, 22100 Lund, Sweden; mariana.chrispim@usp.br \\ 2 School of Arts, Sciences and Humanities, University of São Paulo, Arlindo Bettio Avenue 1000, \\ São Paulo 03828-000, Brazil; fernanda.marco.souza@usp.br (F.d.M.d.S.); mnolasco@usp.br (M.A.N.) \\ 3 Department of Civil Engineering Science, School of Civil Engineering and the Built Environment, \\ University of Johannesburg, Kingsway Campus, P.O. Box 524, \\ Auckland Park 2006, Johannesburg, South Africa \\ 4 Civil Engineering Research Group, School of Science, Engineering and Environment, The University of \\ Salford, Newton Building, Peel Park Campus, Salford M5 4WT, UK \\ * Correspondence: miklas.scholz@tvrl.lth.se; Tel.: +46-703-435-270
}

Received: 30 October 2020; Accepted: 2 December 2020; Published: 9 December 2020

\begin{abstract}
Currently, it is important to develop strategic frameworks to support the selection of sustainable resource recovery solutions. This study applies a new framework for planning, implementation, and assessment of resource recovery strategies for a full-scale wastewater treatment plant (WWTP) in São Paulo megacity. The framework comprises several steps based on case study-specific data and information from current literature. Data were collected from various sources: a survey with a wastewater treatment utility, national and regional databases, and review of local regulations and international literature. Treatment configuration, wastewater and by-products composition, potential demand (for water, energy, and phosphorus), stakeholder identification, and local legislation were thoroughly discussed regarding decision-making on resource recovery. Scenario analysis was used to explore suitable nutrient and energy recovery measures based on indicators. Biogas recovery and sewage sludge composting showed more favorable conditions due to similar experiences in the area and robust legislation. The proposed framework is a simplified tool, and its application can support managers to get information on resource recovery and how to plan such initiatives in easier ways to facilitate wiser decision-making, and better operation and management. The results on framework use and refinement can guide potential applications in other contexts and stimulate public policy formulation and further research.
\end{abstract}

Keywords: decision-support system; resource-oriented sanitation; sewage; integrated process; water-energy-food nexus; dense urban areas; developing countries; energy recovery

\section{Introduction}

The scarcity of natural resources is a driver for initiatives of resource recovery and reuse, by producing biogas, fertilizer, and water that can be returned to the market. Recovering valuable compounds of municipal wastewater includes several important aspects for the planning process, decision-making, and implementation.

Due to the increase of global urbanization, cities are special places for recovery of resources, and wastewater treatment plants (WWTP) are sites where such processes can take place. Wastewater 
treatment facilities are part of the cities' metabolism and the local region; thus, resource recovery processes should be planned in an integrated way. For instance, how the treatment plant could contribute with potential resources to the local industries clusters or agriculture. WWTP should be integrated within the local community and economic activities [1]. Thus, cities have great potential to support the progress towards regional sustainable development [2].

Sustainable Development Goal 11 focuses on making cities inclusive, safe, resilient, and sustainable, and with the inclusion of policies and plans towards resource efficiency, and by 2030, to reduce the adverse environmental impacts of cities with particular attention to waste management [3]. In this context, cities require efficient management of natural resources in the face of growing demands and changing environmental conditions [4].

The incorporation of resource recovery solutions (e.g., water reuse, nutrient and energy recovery) can improve the overall performance of WWTP [5] and contribute to the circular economy in wastewater treatment and urban sustainability [6]. The benefits provided by resource recovery implementation are higher in areas that face stress and low availability or high consumption of resources (e.g., water) [7]. Conservation of water resources should be a priority especially for megacities in developing countries, which face water shortages, water pollution, lack of infrastructure and public services, and a lack of provision of clean water and safe disposal of wastewater and stormwater [8,9]. Megacities, where large WWTP are usually in operation, can improve resource recovery with economic efficiency and profitability while generating environmental benefits such as improvement of surface water quality and mitigation of eutrophication issues [10,11].

However, there is an absence of studies on how to integrate resource recovery technologies in municipal wastewater treatment plants. Some current barriers to implementation of resource recovery from wastewater are: How to combine resource recovery solutions to maximize plant productivity [7,12,13]; and a lack of decision-making tools and methodologies to identify the best solution for each context $[14,15]$. Most literature on resource recovery focuses on the discussion of recovery processes and technologies and not on the interactions with environment and stakeholders (researchers, policymakers, and end-users) [16,17]. Therefore, an integrated approach of potential resource recovery solutions on a real scale is necessary [16] (Table 1).

Table 1. Identified knowledge gaps with key journal paper references and how these gaps are directly addressed by the present paper.

\begin{tabular}{|c|c|c|}
\hline Knowledge Gaps & References of Previous Papers & How this Gap is Addressed in Our Paper \\
\hline $\begin{array}{l}\text { Great potential of application of resource } \\
\text { recovery solutions in megacities; few studies on } \\
\text { nutrient recovery in South American countries }\end{array}$ & {$[9-11,18]$} & $\begin{array}{c}\text { The framework is applied to a representative } \\
\text { WWTP in São Paulo megacity. Additionally, there } \\
\text { is an indication of applicability to other } \\
\text { megacities, considering resource scarcity and } \\
\text { local characteristics. Nutrient recovery options } \\
\text { are assessed. }\end{array}$ \\
\hline $\begin{array}{c}\text { Lack of studies that focus on interactions with } \\
\text { local environment and stakeholders } \\
\text { (integrated approach) }\end{array}$ & {$[16,17,19]$} & $\begin{array}{l}\text { Linkages of sanitation with economic activity } \\
\text { (market demand), social (stakeholders), and } \\
\text { analysis from water-energy-nutrient nexus } \\
\text { perspective (e.g., water consumption in the area). }\end{array}$ \\
\hline $\begin{array}{c}\text { Comparison of resource recovery strategies from } \\
\text { systems' perspective and understanding of } \\
\text { related impacts }\end{array}$ & [20] & $\begin{array}{c}\text { Step } 9 \text { of the framework contains detailed } \\
\text { comparison of different scenarios for energy and } \\
\text { nutrient recovery. }\end{array}$ \\
\hline $\begin{array}{l}\text { Lack of tools and methodologies to identify the } \\
\text { best solution to each context, to support planning } \\
\text { and decision-making }\end{array}$ & [12-14] & $\begin{array}{l}\text { The framework application allows the most } \\
\text { suitable solution to be identified considering } \\
\text { technical, environmental, societal, economic, and } \\
\text { political/institutional indicators. }\end{array}$ \\
\hline $\begin{array}{l}\text { More comprehensive framework for planning, } \\
\text { decision-making, and assessment of any kind of } \\
\text { resource recovery action, including a large set of } \\
\text { indicators and stakeholders' groups. }\end{array}$ & [21-24] & $\begin{array}{l}\text { The proposed framework is tested in a real case: } \\
\text { It is shown to be simple to apply and facilitates } \\
\text { the planning process and the choice of the } \\
\text { recovery technology. Nutrient and energy } \\
\text { recovery scenarios are analyzed in detail. }\end{array}$ \\
\hline
\end{tabular}


Decision-making on urban water infrastructure projects is complex, since it should consider the interactions between infrastructure (e.g., technological options), environmental, institutional, economic, and social characteristics [19]. Several decision-making parameters can be evaluated to choose the optimum recovery technology such as costs (capital and operational expenditures), recovery rate (\%), environmental impacts (heavy metals and organic contaminants), wastewater composition, and market for the recovered product (e.g., phosphate fertilizer) [25]. These parameters should be considered as early as possible, such as at the design stage [23].

Local context characteristics should be carefully examined and considered in the planning process for resource recovery [7,26]. Especially in developing countries, there is insufficient planning to include efficient sanitation systems [27]. Many technical options are available to recover resources from wastewater and sludge; however, some technologies might not be suitable for developing countries, because of the costs and requirements on treatment processes and energy demand [28].

Besides the costs, local legislation can also influence the selection of resource recovery measures [14]. In some cases, legislation can act as a barrier and changes are required, while in others legislation and standards can be drivers for resource recovery implementation. Then, identifying legal and institutional challenges related to resource recovery can assist in the planning of wastewater treatment plants to support strategic decisions.

It is important to develop strategic frameworks to support society (policymakers and general public) in the selection of resource recovery solutions, such as sustainable options for sewage sludge management [22,29]. According to Romeiko [20], it is necessary to compare environmental performances of resource recovery-based wastewater treatment plants to support the design and implementation of resource recovery strategies from system perspectives. This comparison can include several indicators. As a result, a better understanding of resource recovery technologies will allow for the design of future systems [30].

A proposed framework as a tool to stimulate/support planning and decision-making on resource recovery from wastewater treatment was presented by Chrispim et al. [31]. As the next step, this paper presents how this framework can be applied, offers significant suggestions for improvement, and addresses research gaps in the field (Table 1). The aim was to showcase the new framework for planning, implementation, and assessment of resource recovery strategies for a representative WWTP. The specific objectives were to apply all the steps of the proposed framework to support decision-making on resource recovery strategies; to recommend operational and technological strategies of resource recovery (nutrients and energy) to be applied in this representative facility, considering economic, technical, environmental, societal, and political indicators; and to identify strengths and potential improvements of the framework.

In this paper, the case study was a large WWTP in São Paulo megacity and the authors identified current practices and opportunities for improvement of this facility, including processes and technologies for resource recovery. Based on real data from a practice system, it was possible to propose innovations, and to support the implementation of new strategies and more effective solutions for resource recovery from wastewater. Understanding and testing the framework application was an important task to prioritize future data collection efforts.

The results could contribute to the creation of technical and scientific knowledge and a better understanding of planning, retrofitting, and upgrading of municipal WWTP with resource recovery, and to support the development of public policies or regional programs in this area. Wider applicability of the results for other cities is suggested for better wastewater management practices and for supporting resource recovery implementation. Through the framework application, it is possible to address what needs to change to achieve or optimize the resource recovery initiatives. Some key questions addressed in our paper are: What resources are available in the waste streams in the studied plant; what market demand there might be for them; how they could be recovered; what the linkages with local legislation are; and who the key stakeholders are. 


\section{Methods}

\subsection{Developed Framework}

The methodology applied in this paper was based on a framework developed to support the planning and decision processes about resource recovery strategies in wastewater treatment plants [31]. In the cited paper, the framework was just outlined (briefly introduced). The present paper contains novel aspects: The first application in a real situation, suggestions of improvements and new arrangements of the framework, potential impact of its application in world's megacities, and estimation of potential resource recovery solutions for the study region. The framework (Figure 1) was applied in a case study of a wastewater treatment plant in the São Paulo megacity (or the metropolitan region of São Paulo). Wider applicability of the framework is suggested in Table 2.

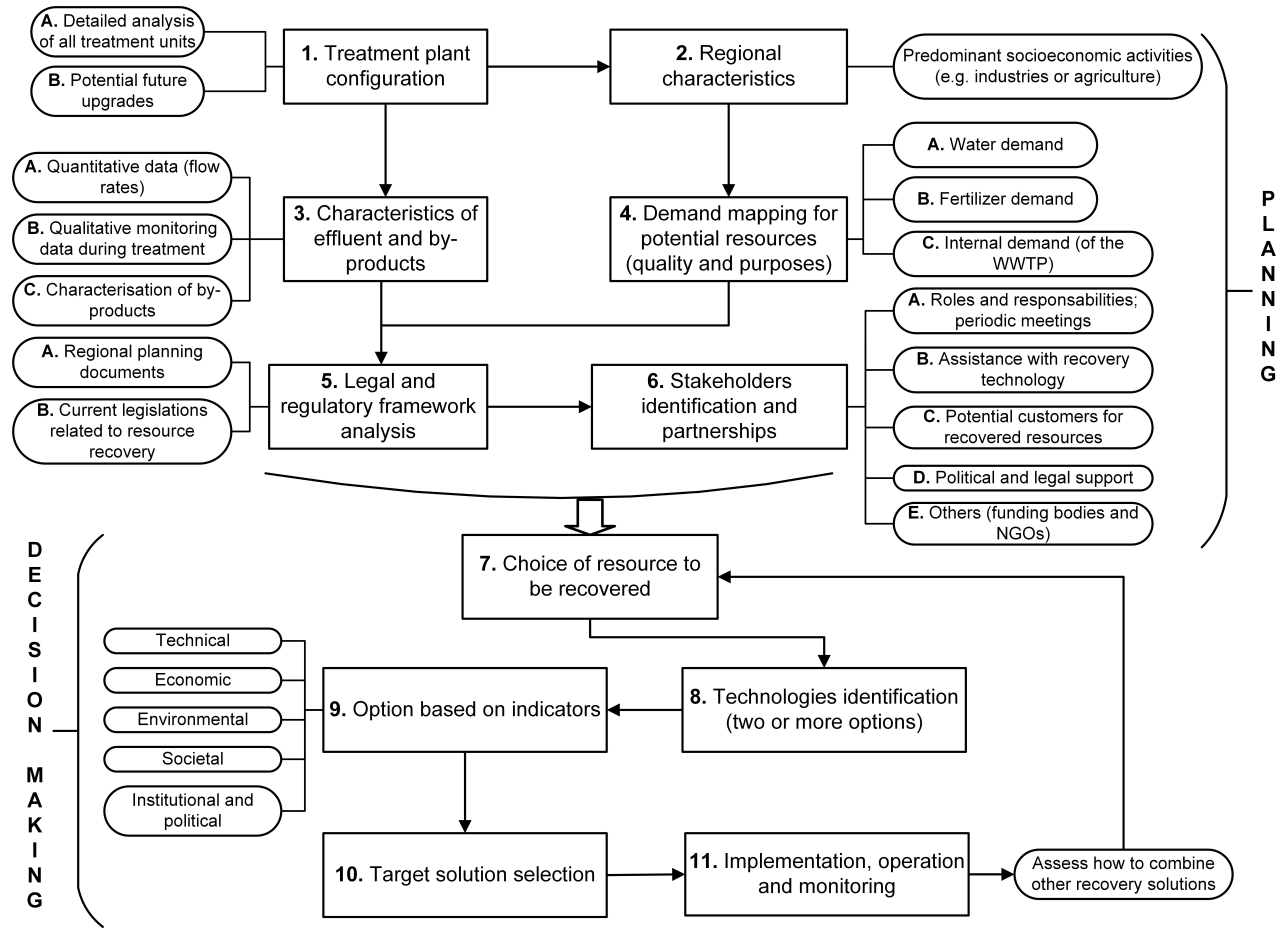

Figure 1. Framework applied in this study (adapted from [31]).

Table 2. Indication of the framework applicability in megacities similar to São Paulo (New York is shown for comparison purposes).

\begin{tabular}{|c|c|c|c|c|c|c|c|c|}
\hline Megacity & $\begin{array}{c}\text { Level of } \\
\text { Applicability }\end{array}$ & $\begin{array}{l}\text { Reliability } \\
\text { Level }\end{array}$ & $\begin{array}{c}\begin{array}{c}\text { Similarity } \\
\text { of }\end{array} \\
\text { Wastewater } \\
\text { Treatment } \\
\text { Characteristics }\end{array}$ & $\begin{array}{l}\text { Demand for } \\
\text { Potential } \\
\text { Resources }\end{array}$ & $\begin{array}{c}\text { Water } \\
\text { Demand; } \\
\text { Water Scarcity }\end{array}$ & $\begin{array}{l}\text { Energy } \\
\text { Demand }\end{array}$ & $\begin{array}{l}\text { Phosphorus } \\
\text { Demand }\end{array}$ & $\begin{array}{c}\text { Expected } \\
\text { Impact of } \\
\text { Framework } \\
\text { Application }\end{array}$ \\
\hline São Paulo & high & high & high & high & high & high & medium & high \\
\hline Mexico City & high & medium & high & high & high & high & medium & high \\
\hline Johannesburg & high & medium & high & high & high & high & low & medium \\
\hline Cairo & medium & medium & medium & medium & high & low & low & high \\
\hline Chengdu & medium & low & low & medium & medium & high & low & medium \\
\hline Shanghai & medium & low & medium & medium & high & medium & low & medium \\
\hline Delhi & high & low & high & high & high & high & high & high \\
\hline New York & low & medium & high & low & low & medium & low & low \\
\hline
\end{tabular}

Notes: Based on expert's judgement of the authors (after consulting with local experts in the area and urban sustainability indexes; Sustainable Cities Water Index [32], Blue City Index [33], and SDEWES Index [34]). The assessment considered not only the demand (and use) for water, energy, and phosphorus, but also if there has been an increase in the resource consumption (e.g., electricity), its current availability, and if it represents a key issue for the city. São Paulo, Mexico City, Cairo, and Delhi refer to their metropolitan areas, Johannesburg, Chengdu, and New York to urban agglomerations, and Shanghai is the city proper (based on classification from the United Nations [35]). 


\subsection{Studied WWTP}

The information regarding the plant was gathered with the support of the São Paulo State Water Supply and Sewerage Company (SABESP), who owns and operates this facility. The wastewater treatment plant ABC is located in São Paulo city $\left(23^{\circ} 36^{\prime} 41.58^{\prime \prime} \mathrm{S}\right.$ and $46^{\circ} 35^{\prime} 9.24^{\prime \prime}$ W) (Figure 2). This facility treats sewage from six cities, totalizing an approximate population equivalent of 1.4 million inhabitants.

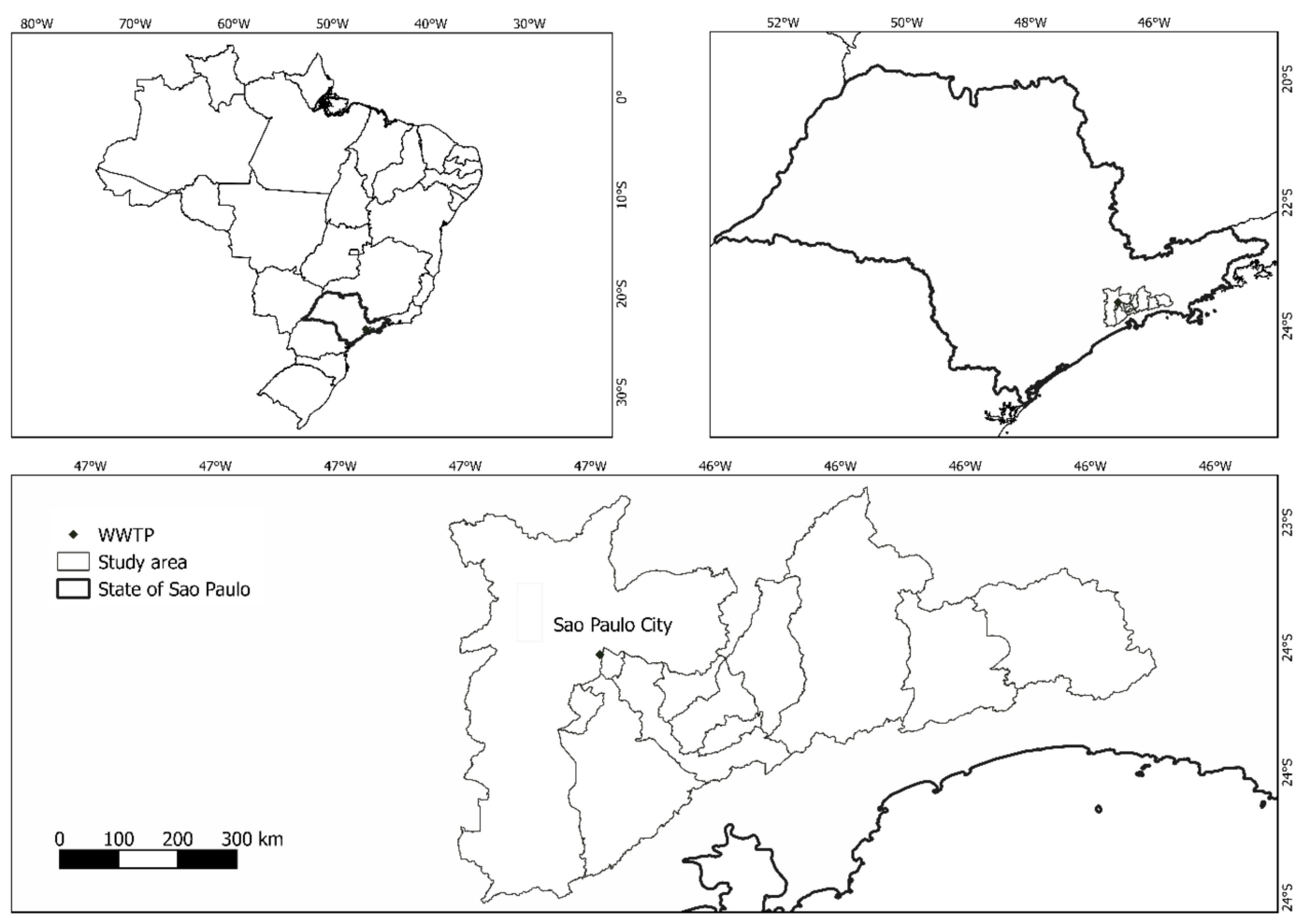

Figure 2. Map of the study area.

This plant started up in 1998, with a maximum treatment capacity of $3 \mathrm{~m}^{3} / \mathrm{s}$, and it is foreseen to increase this capacity (Section 3.1.1). The mean wastewater inflow rate was $2.33 \mathrm{~m}^{3} / \mathrm{s}$ during the analyzed period (07/2016 to 06/2017). The treatment processes for liquid and solid phases are illustrated in Figure 3. A detailed description of treatment stages is given in Section 3.1.1. Detailed information about the study area is presented in Section 3.1.2.

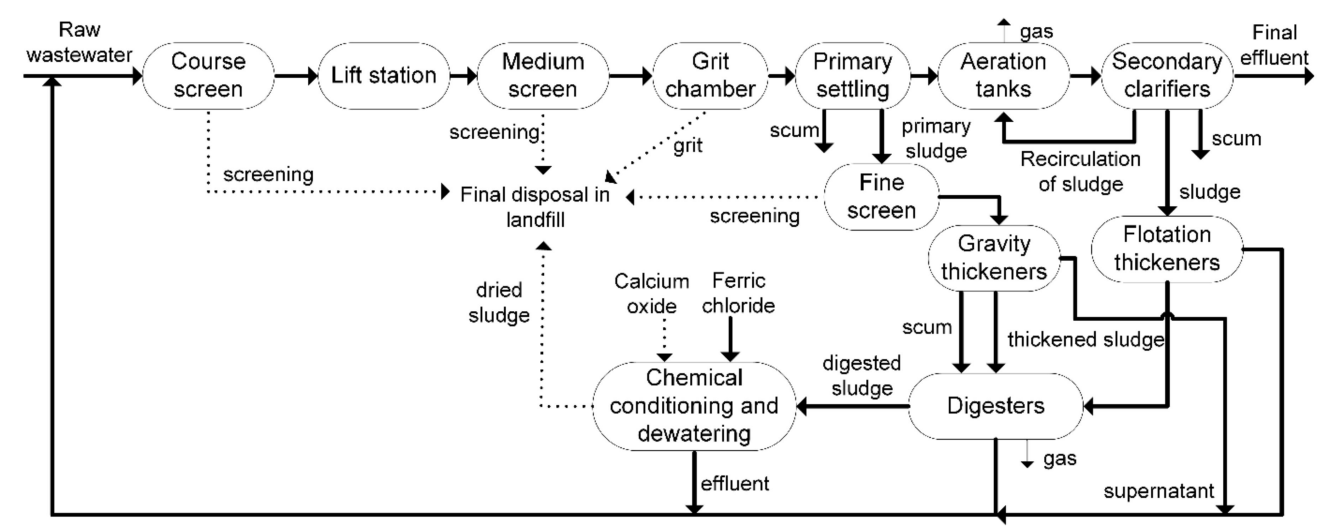

Figure 3. Diagram of the wastewater treatment plant ABC with all the treatment processes and flows. Notes: Wide arrows: Liquid state; dashed arrows: Solid state; thin arrows: Gaseous state. On the final 
arrows that do not have continuity in another unit operation: Final effluent, part is discharged in the river, part is conducted to a non-potable water reservoir, and part is sent to the Aquapolo Project; scum from settling tanks is conducted to digesters or disposed in landfill.

The motivation for the choice of this plant was based on the availability of data, its completeness, representativeness (in terms of scale, treatment flow, and treatment processes compared to other large-scale WWTPs of São Paulo megacity), and because this plant already applies one measure of resource recovery: Water reuse. It is noted that Cornejo et al. [36] also used similar criteria to choose WWTP in their study.

\subsection{Data Collection for Application of The Framework in the Case Study}

The input data to achieve steps 1,3 , and $4 \mathrm{C}$ of the framework (treatment configuration; qualitative and quantitative characterization of effluent and by-products; and identification of internal demand) were obtained with the managers and engineers of the plant (WWTP ABC). For this, a list of the necessary primary data (general data, characteristics of the treatment processes used, monitoring data, by-products, and environmental indicators) was prepared (Supplementary Material S1).

For characterization purposes (step 3), the substances considered for analysis were: Water, phosphorus, nitrogen, and organic matter. The water (treated effluent, reclaimed water, and water consumed by the WWTP) represents a relevant local resource for the context of the study area. Phosphorus $(\mathrm{P})$ is a resource that is globally limited, and it presents actual scale recovery processes implemented in several countries where it is considered economically viable. In addition, $\mathrm{P}$ can be recovered from different units of wastewater treatment processes. Nitrogen is an important constituent (in quantitative terms) of municipal sewage, as well as $\mathrm{P}$, and has potential as fertilizer. Organic matter is source for recovery of many products (e.g., energy from biogas and soil conditioner). Further information on research design is presented in the Supplementary Material S2 (2A).

The temporal boundary of the analysis comprised a period of one year (from 07/01/2016 to 06/30/2017). The definition of this period followed the recommendation of Brunner and Rechberger [37], and it was considered a reasonable period to determine reliable average values, since the period should be enough to counterbalance momentary instabilities of the analyzed system and seasonal variations. The analysis included all processes and unit operations of the WWTP ABC from the arrival of raw wastewater until the discharge of treated effluent (Figure 3).

The data to achieve the other steps of the framework were collected from various sources, consulting the related legislations on water reuse, sludge recycling (in the form of organic fertilizer and soil conditioner) and energy recovery, technical reports, regional databases, journal articles, and planning documents for the study area. For step 4, in order to complement the data (estimated volume and price of reclaimed water for non-potable uses in urban areas), we contacted the plant managers of WWTP that commercialize reclaimed water and the responsible secretaries of the city council of study area cities.

The comparison of recovery technologies options (step 9) considered evidence from the literature about the respective technologies. Scenario analysis was used to explore some possible resource recovery measures for the studied plant. Detailed information for each attribute/indicator can be found in the Supplementary Material S3.

\subsection{Data Analysis}

After data collection, both qualitative and quantitative data were organized into data spreadsheets for comparison purposes. Based on the collected raw data about the plant, mean concentrations, organic and nutrient loads, and removal efficiencies for the main parameters chemical oxygen demand (COD), biochemical oxygen demand (BOD), nitrogen (N) and P were calculated. In general, the results were represented as tables and graphs. The final step was the comparison between the recovery options according to the indicators. The outlook (recovery scenarios) was a result of the different assessment indicators given in this work (educated guesses) and based on the literature. 


\section{Results and Discussion}

\subsection{Application of the Proposed Framework for Resource Recovery in a WWTP in São Paulo Megacity}

The results are organized and discussed according to each step of the proposed framework. Further information on each step is in Supplementary Material S2B-H.

\subsubsection{Step 1-Existing Treatment Configuration}

The first step of the framework included liquid and solid phases and the analysis of all the existing treatment units in the plant (Figure 3) as well as the expected upgrades for this facility. Detailed characteristics of all treatment units are summarized in Supplementary Material S2B.

Future upgrades of the studied plant are changes to increase its treatment capacity. The expected upgrades are to increase to $6 \mathrm{~m}^{3} / \mathrm{s}$, and a further stage to upgrade the settling tanks to increase the treatment capacity to $8.5 \mathrm{~m}^{3} / \mathrm{s}$. Currently, it is foreseen that there will be an increase of the treatment capacity to $4 \mathrm{~m}^{3} / \mathrm{s}$ in 2023. It is important to take it into account when planning resource recovery strategies since the increase of the plant's capacity will imply increase of generated by-products (e.g., sludge) and will have effects on characterization (effluent and sludge quality).

\subsubsection{Step 2-The Surrounding Areas of the WWTP}

Understanding the local context is a crucial step to support future decisions about which resource(s) to recover. Firstly, we defined the area nearby the WWTP. The named group 1 includes the municipalities of the Great ABC Region (Santo Andre, São Bernardo do Campo, São Caetano do Sul, Diadema, Maua, Ribeirao Pires, and Rio Grande da Serra) and São Paulo city. Furthermore, a broader area (group 2) was considered, including four other municipalities of the metropolitan region of São Paulo (MRSP) (Biritiba-Mirim, Mogi das Cruzes, Salesópolis, and Suzano) due to their importance to agricultural activity (high values added to agriculture among the cities of the MRSP). Figure 2 shows the study area, comprising cities of groups 1 and 2. The main economic sectors correspond to those with the highest contribution to gross domestic product in the study region (groups 1 and 2). Figure 4 shows the distribution of the main economic activities in terms of the number of facilities in the study region.

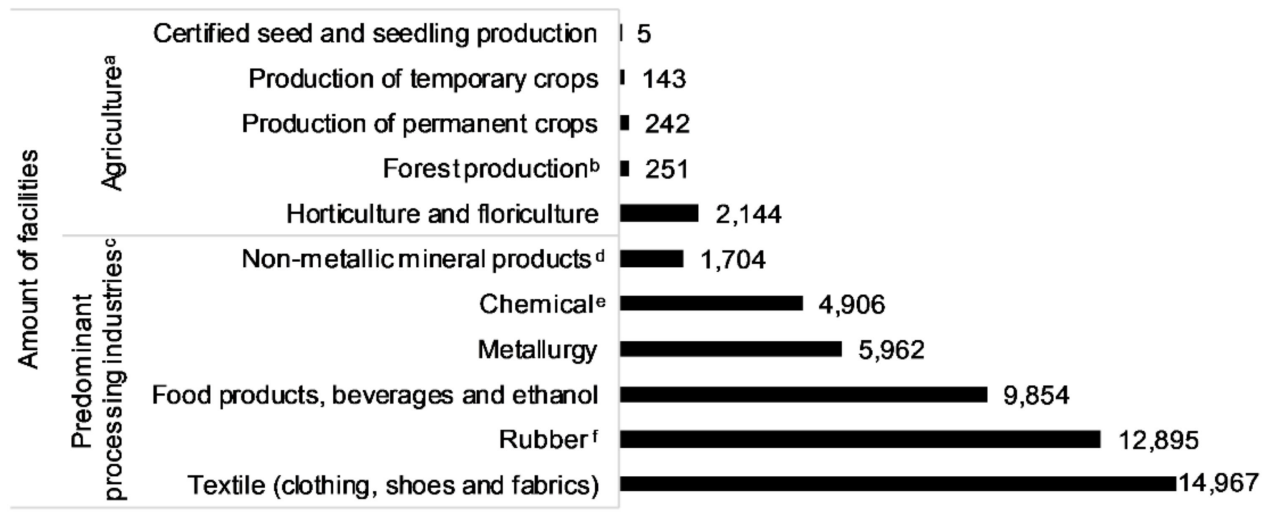

Figure 4. Predominance of agricultural and industrial activities in the surrounding area of the wastewater treatment plant. Notes: (a) Based on the Brazilian Institute of Geography and Statistics (IBGE) [38]; data refer to 2017; (b) it includes planted and native forests; (c) based on [39]; data refer to January to September of 2019; the automobile sector is not included. Other sectors were not included because they are not highlighted in the Great ABC region [40]. Other sectors correspond to the mechanical industry; electrical and communications industry; transport material industry; wood and furniture industry; paper, cardboard, editorial, and graphic industry; and footwear industry (23,390 facilities in total); (d) manufacturing of materials such as cement; (e) industries such as pharmaceutical, veterinary, perfumery, and others; (f) smoke, leather, fur, and similar industries. 
In the group 1 region, there is a predominance of processing industries and other services (transport, post office; accommodation and food; information and communication; private education; health; among others) [41]. The main processing industries are automobile industries, chemical industries, metallurgy industries, rubber and plastic production, food industries, and textile [40].

Agriculture and livestock are not significant economic activities in the group region 1. Nevertheless, in the small city of Rio Grande da Serra, there is considerable agricultural activity (fruit and vegetable production and farms for chicken production) [42]. In quantitative terms, there are 5064 units considering agriculture, forestry, plant extractivism, and livestock in group 2 (considering the 12 municipalities) [39]. It is worth adding that in the rural zone of São Paulo city, there are about 428 units of agricultural production, particularly in the southern region, for fruit, ornamental, and leave crops [43].

In the analyzed region (group 2), the quantity of settlements is higher in horticulture and floriculture [38]. In addition, there are initiatives such as: Urban agriculture programs in Diadema and Santo Andre, community gardens in São Paulo city [44], and vertical farming. The products of horticulture in the region are diverse, but the crops linked to the highest number of farms are lettuce, cabbage, and coriander [45]. Therefore, this diagnostic (step 2) can support the identification of the local area needs and the potential demand for resources that could be recovered by the studied WWTP, which is discussed in step 4.

\subsubsection{Step 3-Qualitative and Quantitative Characteristics of the Treated Effluent and by-Products}

This step allows for the support of decisions on what recovery measures would be feasible for a specific facility. It is possible to identify resources that are present in which treatment stages and in what quantities. The analysis was based on the volumes of wastewater, consumption of inputs, and generation of waste in the period of one year. All treatment processes are summarized in Figure 3.

Regarding quantitative data, the average daily raw wastewater flow rate that entered the plant was $2.33 \mathrm{~m}^{3} / \mathrm{s}$. The total volume of the raw wastewater inflow rate during the analyzed period was $73,720,195 \mathrm{~m}^{3}$ and the total volume of treated effluent was 71,266,865 $\mathrm{m}^{3}$ per annum. Part of the treated effluent by the plant was discharged into the river nearby, another part was directed to the Aquapolo Project ( $423 \mathrm{~L} / \mathrm{s}$ during the monitored period), and a third part went to an internal reclaimed water facility. This reclaimed water was used internally for washing of streets and installations, sealing of pumps, cooling equipment, and foam breaking.

The Aquapolo Project is the largest wastewater reuse facility in the southern hemisphere, and the fifth largest of its kind in the world. In the Aquapolo Project, the advanced treatment processes used are disk filters ( 400 microns), membrane bioreactor (0.05 microns), and reverse osmosis [46]. After this treatment, the reclaimed water is pumped to a Petrochemical Complex, mainly for cleaning of cooling towers and boilers [46]. The current capacity is to provide up to $650 \mathrm{~L} / \mathrm{s}$ of water to the industrial complex [47].

Steps 3B and 3C (Figure 1) comprise the qualitative monitoring of the treated effluent and the by-products (Tables 3 and 4 ) to identify potential resources to be recovered. The removed grit and screening material are currently sent to landfills. The annually removed amount was about $765,755 \mathrm{~kg}$ of grit and 152,641 kg of screening material. The generation of screening material was $2.07 \mathrm{~kg}$ per $1000 \mathrm{~m}^{3}$ of raw wastewater (plant influent) and $10.38 \mathrm{~kg}$ of grit per $1000 \mathrm{~m}^{3}$. The generation of screening material was lower than the findings of a previous study [48]: Average of $6 \mathrm{~kg}$ per $1000 \mathrm{~m}^{3}$, but in other WWTP in the São Paulo state. It is worth noting that the data on generated screening material and grit (of our studied plant) were underestimated due to maintenance of the equipment during part of the monitored period, which can explain the lower value. 
Table 3. Quantitative data of by-products of the wastewater treatment plant (WWTP) and potential resources.

\begin{tabular}{|c|c|c|c|c|}
\hline Unit & Material & Quantity ${ }^{b}$ & Unit & $\begin{array}{c}\text { Resources with Potential } \\
\text { to be Recovered }\end{array}$ \\
\hline Screening & Screening material ${ }^{a}$ & 554.55 & $\mathrm{~kg} /$ day & Energy \\
\hline Grit chamber & Grit & 3175 & $\mathrm{~kg} /$ day & Grit \\
\hline \multirow{2}{*}{ Primary settling } & Sludge & 1093.8 & $\mathrm{~m}^{3} /$ day & Energy \\
\hline & Scum & 0.864 & $\mathrm{~m}^{3} /$ day & Energy \\
\hline \multirow{2}{*}{ Secondary clarifier } & Sludge & - & - & - \\
\hline & Scum & 9.09 & $\mathrm{~m}^{3} /$ day & Energy \\
\hline \multirow{2}{*}{$\begin{array}{l}\text { Gravity thickeners } \\
\text { Flotation thickeners }\end{array}$} & Thickened sludge & 748.7 & $\mathrm{~m}^{3} /$ day & Nutrients \\
\hline & Thickened sludge & 250.36 & $\mathrm{~m}^{3} /$ day & Nutrients \\
\hline \multirow{2}{*}{ Digesters } & Digested sludge & 1215.75 & $\mathrm{~m}^{3} /$ day & Nutrients \\
\hline & Biogas & $3036^{c}$ & $\mathrm{Nm}^{3} /$ day & Energy \\
\hline $\begin{array}{l}\text { Chemical conditioning } \\
\text { and dewatering of } \\
\text { sludge }\end{array}$ & $\begin{array}{l}\text { Digested and dried } \\
\text { sludge }\end{array}$ & 112.9 & ton/day & $\begin{array}{c}\text { Fertilizer (P or biosolids) } \\
\text { Energy }\end{array}$ \\
\hline
\end{tabular}

Table 4. Mean concentration of main parameters at different sampling points.

\begin{tabular}{|c|c|c|c|c|c|}
\hline Parameter & $\begin{array}{l}\text { Influent (Raw } \\
\text { Wastewater) }^{a}\end{array}$ & $\begin{array}{l}\text { Final Effluent } \\
\text { (Treated) }^{b}\end{array}$ & $\begin{array}{l}\text { Thickeners } \\
\text { (by Gravity) } \\
\text { Supernatant }\end{array}$ & $\begin{array}{l}\text { Thickeners } \\
\text { (by Flotation) } \\
\text { Supernatant }\end{array}$ & $\begin{array}{c}\text { Dewatering } \\
\text { Centrate }\end{array}$ \\
\hline $\mathrm{COD}(\mathrm{mg} / \mathrm{L})$ & 462.2 & 66.0 & 6970.0 & 118.3 & 1250.0 \\
\hline $\begin{array}{c}\text { Dissolved COD } \\
(\mathrm{mg} / \mathrm{L})\end{array}$ & 124.8 & 83.3 & - & - & - \\
\hline $\mathrm{BOD}_{5,20}$ & 241.0 & 30.3 & - & - & - \\
\hline $\begin{array}{l}\text { Total Phosphorus } \\
\text { (mg/L) }\end{array}$ & 14.8 & 3.9 & 23.9 & 3.8 & 6.1 \\
\hline $\begin{array}{c}\text { Dissolved } \\
\text { phosphorus (mg/L) }\end{array}$ & 2.4 & 1.8 & 10.0 & 2.1 & 4.4 \\
\hline $\begin{array}{l}\text { Total nitrogen } \\
(\mathrm{mg} / \mathrm{L})\end{array}$ & 33.2 & 25.1 & - & - & - \\
\hline
\end{tabular}

Notes: ${ }^{a}$ Sampling point located at the entrance of the ABC WWTP (before grit chamber); ${ }^{\mathrm{b}}$ effluent of secondary clarifier. "-": data not available due to no measurement.

The total amount of produced dewatered sludge (or biosolids, which refer to stabilized sewage sludge) was 41,190 tons in the analyzed period (one year). The WWTP ABC had higher sludge production compared to a similar study [49], which obtained 2894 tons annually of biosolids produced in a WWTP in USA with a flow rate of $0.541 \mathrm{~m}^{3} / \mathrm{s}$ using activated sludge process. However, it is emphasized that the amount of sludge produced depends on the treatment flow rate, the treatment processes used, and the composition of sewage.

In the anaerobic digestion of sewage sludge (of WWTP $\mathrm{ABC}$ ), the mean biogas composition was $69.79 \%$ of $\mathrm{CH} 4$ (methane), $27 \%$ of $\mathrm{CO}_{2}$ (carbon dioxide), $2.7 \%$ of $\mathrm{N}_{2}$ (nitrogen), $0.59 \%$ of $\mathrm{O}_{2}$ (oxygen), and $<30 \mathrm{ppm}$ of $\mathrm{H}_{2} \mathrm{~S}$ (hydrogen sulfide). The methane production was about $2118.8 \mathrm{Nm}^{3} /$ day. Estimates regarding electric power generation from methane production are discussed in Section 3.1.7.

In the studied plant, the removal efficiencies were: $85.7 \%$ COD, $24.5 \%$ total $\mathrm{N}$, and $73.5 \%$ total $\mathrm{P}$. The COD load was $93,350 \mathrm{~kg} /$ day. The total P load that entered the plant during the analyzed period was $2997 \mathrm{~kg} / \mathrm{d}$, which totalized around 1094 tons/year. The total $\mathrm{N}$ load that entered the WWTP ABC was $6707 \mathrm{~kg} /$ day, or 2448 tons/year. Considering that $73.5 \%$ of the $\mathrm{P}$ total load was removed by the 
studied plant, which ended up in the sewage sludge, the content of $\mathrm{P}$ was estimated to be around 2.2 tons $P$ per day in the sludge.

Analyzing the waste stream composition is essential to the selection of suitable resource recovery technologies. Different technologies may have strengths and weaknesses in targeting specific wastewater components [23]. Data for P concentration (Table 4) in secondary streams allow for technology options for recovery to be defined. The highest $\mathrm{P}$ concentration was observed in the supernatant from the gravity thickeners. There was no monitoring of $\mathrm{P}$ concentration in the supernatant of digesters. In the case where the nutrient concentration was below $20 \mathrm{mg} / \mathrm{L}$, it was recommended to apply accumulation techniques such as: Wetland or microalgae cultivation, and physicochemical treatment [50]. There was no monitoring for nutrient content in sludge for the studied facility. However, a recent study [51] reported the mean value of $16.4 \pm 2.1$ ( $\mathrm{g} \mathrm{P} / \mathrm{kg}$ of dewatered sludge) for the studied plant (ABC).

Characterization of influent and effluent quality of WWTP provided useful information for designing strategies and selecting processes for resource recovery $[5,52]$. The next steps aimed to guide on how the WWTP could be improved, defining strategies for recovering resources.

\subsubsection{Step 4-Mapping the Demand for Recovered Resources}

This step aimed to identify the needs for resources (water, nutrient, and energy) in the local context as well as potential customers (e.g., industries, farmers, and households) for recovered products. Consumption of water, electricity, and fertilizers in the surrounding area and internally in the plant is presented in Table 5.

Table 5. Estimated demand for the wastewater treatment plant and nearby locations for resources.

\begin{tabular}{|c|c|c|c|c|}
\hline Demand & Sector & Water (m³/month) & $\begin{array}{c}\text { Electricity } \\
\text { (kWh/month) }\end{array}$ & $\begin{array}{c}\text { Fertilizer } \mathrm{P}_{2} \mathrm{O}_{5} \\
(\mathrm{~kg})\end{array}$ \\
\hline \multirow[t]{3}{*}{ External } & $\begin{array}{l}\text { Processing } \\
\text { industries }\end{array}$ & $\begin{array}{c}\text { 1,124,786 (food and } \\
\text { beverage); 1,020,714 } \\
\text { (chemical); } 436,314 \\
\text { (textile); } 367,722 \\
\text { (metallurgy); } 247,293 \\
\text { (rubber); 206,790 } \\
\text { (non-metallic mineral } \\
\text { products); and 168,714 } \\
\text { (automobile) }^{\text {a }}\end{array}$ & $50,450^{\mathrm{e}}$ & - \\
\hline & Agriculture & $761,271^{b}$ & - & $\begin{array}{c}132,139 \mathrm{~g} ; \\
93,961^{\mathrm{h}}\end{array}$ \\
\hline & Urban purposes & $5450^{c}$ & $\begin{array}{c}222 \text { (households), } \\
23,210 \text { (public } \\
\text { lighting), } 2352 \\
\text { (stores/shops) }^{\mathrm{f}}\end{array}$ & - \\
\hline Internal & WWTP analyzed & $6622^{d}$ & $2,598,708$ & - \\
\hline
\end{tabular}

Notes: ${ }^{\text {a }}$ Based on [53], referring to 2015 and the study region (12 municipalities), considering only predominant industrial sectors; ${ }^{b}$ data refer to 2015; based on [54] (data not available for four cities without predominant agricultural practices); ${ }^{\mathrm{c}}$ data from [55]; referring to November 2019; ${ }^{\mathrm{d}}$ potable water consumption (June 2016 to July 2017); ${ }^{\mathrm{e}}$ mean consumption per industry in São Caetano do Sul city; for all types of industries [56]; ${ }^{\mathrm{f}}$ mean consumption per unit in São Caetano do Sul city [56]; ${ }^{g}$ total fertilizer sold per planted area in the study area (data not available for five cities, which do not have predominant agriculture activity); based on [57] referring to 2014; $\mathrm{h}$ total fertilizer used in the studied area (data not available for five cities as mentioned) based on [58], referring to 2015, planted area obtained from [59] and referring to 2016; “_" not applicable.

In Brazil, the highest water demand from industries is in São Paulo state $\left(59.7 \mathrm{~m}^{3} / \mathrm{s}\right)$. The industries of manufacturing of food products, beverages, cellulose and paper, petroleum products, biofuels, chemical products, and metallurgy correspond to $90 \%$ of the flow of the water consumption by the national industry [60]. The quality required for industrial uses is highly variable, depending on the 
sector and level of process sophistication. A further step could be to analyze the quality of the treated effluent to find out if it could meet the specific quality requirements of one industry or a group of them in the same sector. Then, it is possible to evaluate the need for additional treatment to water reuse.

In quantitative terms, in some sectors such as paper and cellulose, chemical products, textile, and cement industries, the water consumed for cooling (non-contact) can represent up to $94 \%, 95 \%$, $57 \%$, and $82 \%$ of the total water consumption, respectively [61,62]. It is worth noting that industries of chemical and textile sectors are predominant in the studied region and represent high water consumption rates (Figure 4 and Table 5).

Other important water use is agricultural irrigation. In Brazil, the south-eastern region corresponds to the largest irrigated area for agriculture; $34 \%$ of the total irrigated area [63]. Reclaimed water could be used for irrigation in agriculture, but currently there is not yet local regulation for water reuse for agricultural irrigation in the state of São Paulo.

The demand for non-potable urban purposes (irrigation of parks, squares, public cleaning, clearing of rainwater galleries, and sewage networks) was based on the volume reported by one plant as commercialized to urban purposes in São Paulo city (Table 5). Comparing the total water demand for the predominant industries, agriculture and urban use $\left(4,339,054 \mathrm{~m}^{3} / \mathrm{month}\right)$ (Table 5) and the treated effluent flow that is discharged into the river $\left(4,341,600 \mathrm{~m}^{3} / \mathrm{month}\right)$ by the studied plant, if directed to reuse, this flow would be sufficient to supply all the water demand for these corresponding purposes.

Electricity consumption data were collected for São Caetano do Sul city, which is close to the WWTP (Table 5) [56]. Regarding the internal demand of the plant, the average energy consumption of WWTP ABC was about $2.6 \mathrm{GWh} / \mathrm{month}$ (consumption for all processes). Considering the volume of treated sewage, the energy consumption corresponds to $0.42 \mathrm{kWh} / \mathrm{m}^{3}$ of treated sewage.

In this paper, the local market value (of phosphate fertilizer, water, and electricity) was estimated to make the analysis more complete. The price for potable water is dependent on the consumed volume. Based on SABESP (service provider), the current fee for potable water in São Paulo city varies from $3.6 €$ per $\mathrm{m}^{3}$ (for consumption higher than $50 \mathrm{~m}^{3} /$ month) to $9.3 €$ per month (for consumption lower than $10 \mathrm{~m}^{3} /$ month) in commercial, industrial, and public sectors [64]. This value varies among the cities. Regarding the reclaimed water, there is no standard price for the reclaimed water from treated effluent. According to information from one WWTP in São Paulo city, which sells reclaimed water, the price varies from $0.4 € / \mathrm{m}^{3}$ and $1 € / \mathrm{m}^{3}$, depending on the consumed volume and type of contract [55]. The price of phosphate fertilizers (monoammonium phosphate (MAP)) was estimated as $315 €$ per ton in 2017 [65] and superphosphate was $214 €$ per ton in 2019 [66].

Regarding other megacities, Table 2 provides an indication on which resources (water, energy, or P) are scarce in each megacity, supporting the identification on where resource recovery technologies could be more beneficial. Moreover, detailed sustainability assessments considering stresses based on local data are necessary to identify the most suitable technologies to each context [7].

\subsubsection{Step 5-Relevant Legal and Regulatory Framework}

In Brazil, legislation (regulation, quality standards, and requirements) related to wastewater treatment focuses more on standards for discharging the treated effluent than on standards for water reuse. In this section, current legislations related to water reuse, energy and nutrient recovery are addressed.

At a national level in Brazil, there are two national regulations for non-potable reuse: National Water Resources Council (CNRH) 54/2005 and CNRH 121/2010. The first defines general criteria for non-potable direct reuse, while the second establishes guidelines for non-potable direct reuse in agriculture and forestry. The states and municipalities may have more restrictive laws and regulations than the national ones [67].

In the state of São Paulo, where this study took place, the joint resolutions SES/SMA/SSRH n.1 (2017) and SES/SIMA n.1 (2020) govern the non-potable direct reuse of water for urban purposes, originated from WWTP, and establish guidelines and general criteria. There are quality standards 
for uses (e.g., landscape irrigation, washing of streets and other public and private spaces, and civil construction). Irrigation for agricultural uses, grazing and forestry is not included. The WWTP must have at least secondary treatment, disinfection, and filtration, and meet the quality standards and a microbiological characterization of the treated effluent $[68,69]$.

In the state of São Paulo, there is also a decree (48138/2003), which determines some measures for the rational use of water, among which is the prohibition of use of potable water for cleaning streets, squares, and sidewalks, except in specific cases [70]. The Environmental Agency of the State of São Paulo (CETESB) has guidelines for irrigation in agriculture with treated effluent. The application is permitted for fruit gardens, raw uneaten crops, forage (except for direct grazing), reforestation areas, and forest plantations, and establishes some restrictions regarding areas of application and effluent monitoring (heavy metal concentration, thermotolerant coliforms, helminth eggs, sodium adsorption ratio, and electrical conductivity) [71,72]. At the city level, some legislations to promote water reuse from treated effluents for urban non-potable purposes are mentioned in Supplementary Material S2F.

The main barriers to water reuse projects are: No federal program or financial incentives for planning and implementation of water reuse projects (e.g., loan guarantees, tax-free); there are no nationally or locally defined goals (e.g., no obligations or incentives for industries to reuse); the criteria for urban reuse adopted (resolutions n.1/2017 and n.1/2020) in the state of São Paulo are perceived as very restrictive, do not consider agricultural irrigation, and hinder urban reuse [67]. Appropriate policies and the establishment of water quality regulations are required to encourage the creation of markets and the development of water reuse technologies [19].

Regarding energy recovery, the relevant legal and regulatory framework is discussed below. There is a regulation (SMA-079/2009) from the Environment Secretary of the State of São Paulo, which provides guidelines and conditions for operation of thermal treatment of solid waste for energy recovery (e.g., incineration of biosolids) [73]. The Brazilian Electricity Regulatory Agency (ANEEL) establishes the general conditions for the access of microgeneration and mini-generation to the electricity distribution systems (resolution 482/2012). In the case of self-producer, the electricity generated is to meet, partially or totally, the consumption needs of the producer, although the sale of eventual surplus energy may be authorized by ANEEL (law 9427/1996, [74-76]).

In Brazil, biomethane from wastes is an emerging biofuel, and the legal framework for biogas and biomethane recovery has been developed, especially for the state of São Paulo [77]. The regulations in the state of São Paulo about biomethane production are in Supplementary Material S2F. The state decrees n. 60,001 (2013) and 60,298 (2014) provide economic benefits (tax deductions) to utilities that recover biogas or biomethane $[78,79]$.

The national regulation (CONAMA 498/2020) [80] defines the criteria and requirements for production and application of treated municipal sewage sludge (biosolids) in soil. Some requirements are environmental permission, treatment processes, criteria for application, and frequent monitoring of the biosolids quality depending on application. This regulation also defines conditions for cultivation of food crops consumed raw and crops whose edible part has contact with the soil as well as for pasture and forages, food crops that are not consumed raw, fruit trees, and non-food crops [80]. This regulation [80] has been recently published and has updated the previous regulation [81]. It expands opportunities for use of sewage sludge, and in general is more flexible than the previous regulation (in terms of frequency of analyses, guidelines for application, and permitted uses). Therefore, it is expected that this new practice of biosolids for agricultural use will be more widespread in the national territory, contributing to organic matter and nutrient recycling. Biosolids as a product to be applied in soil for agriculture must be registered in the Brazilian Ministry of Agriculture, Livestock and Food Supply (MAPA). It is also possible (based on standard n. 06/2016 of MAPA) [82] to register sewage sludge as a raw material, and to send it externally to a fertilizer or soil conditioner production process. More detailed information about standards on biosolids fertilizer and soil conditioner are in Supplementary Material S2F.

Besides legislation, regional planning documents were consulted (Master Plan of Great ABC region, Municipal Master Plans, Municipal Plan of Sanitation, and others) to identify whether they 
mention resource recovery from wastewater and/or set goals for implementation. The Policy on Climate Change of the State of São Paulo encourages the methane recovery from anaerobic digester of WWTP [83]. The Action Plan on Climate Change in the Great ABC mentions as strategic the biogas recovery from wastewater treatment plants to reduce GHG emissions. In addition, this plan states that sludge generated by the plants is disposed in landfills and has not explored its energy potential [84]. Municipal master plans (Mogi das Cruzes and São Caetano do Sul cities) mention, as one of their guidelines for the promotion and stimulation through tax incentives, the reuse from WWTP-treated effluent. The Municipal Plan of Sanitation of São Paulo states that new arrangements of reuse of sewage sludge for agriculture and civil construction as well as energy recovery from biogas are studied and highlight the potential of expansion of water reuse from treated effluent [85].

The analysis of the local institutional environment (addressed in step 5) allows for checking whether there is legal compliance and availability of supportive incentives [86]. Consequently, these results support the definition of resource recovery scenarios.

\subsubsection{Step 6-Stakeholders Identification}

The stakeholders (groups and institutions) are those interested in resource recovery measures, the potential beneficiaries, those who may be impacted by these measures, and the ones that have power to influence the process [29,87]. In our framework, stakeholders were divided into groups (Figure 1) based on their main roles. The stakeholders for assistance with recovery technology, research, and innovation include universities and research institutes as well as private companies in the region. We considered stakeholders mainly in the municipalities close to the plant: São Paulo city, São Caetano do Sul, Santo Andre, São Bernardo do Campo, and Diadema. Some stakeholders identified were universities that offer undergraduate and postgraduate courses in environmental science and engineering fields and conduct scientific research in related topics, research groups, and private companies on resource recovery technologies. Another group of stakeholders is the potential customers or end-users for the recovered product. It includes the main local farmer associations, trade and industrial associations of the study area, and others. All the mapped stakeholders are listed in Supplementary Material S2G.

The identification of stakeholders should also consider governmental agencies active in the field (e.g., water, energy, and agriculture sectors) that act as intermediary and have control on operation [88]. Thus, stakeholders regarded with political and legal support should be considered such as local governments, authorities, and environmental regulatory organizations. Some examples are water resources managers and the river basin committees, municipal secretaries of environment, and the Secretary of Agriculture. Additional stakeholders could be mapped such as the ones to provide funding or stakeholders supporting public awareness activities related to resource recovery acceptance (e.g., non-governmental organizations (NGO)).

During this process (step 6), potential roles and responsibilities should be assigned to different stakeholders and how they can engage and collaborate in the framework application towards resource recovery implementation. Some examples of key roles for universities and research institutes are to perform laboratorial analysis to ensure the quality of the product, to perform risk analyses, life-cycle assessments, and experimental studies, while NGO or public authorities could assist by awareness raising and promotion of resource recovery approach among the public. The company in charge of providing wastewater treatment services owns the studied plant and their plant managers or board of directors are important stakeholders. In our case study of the framework application, it was considered hypothetically that the water and sanitation provider would manage and coordinate the resource recovery system. We highlight that the list of stakeholders (Supplementary Material S2G) is not exhaustive and can be updated in the future.

All the identified relevant stakeholders could contribute with their opinions and participate actively in the resource recovery project formulation, which would result in an acceptable solution within the local context. Thus, design strategies could incorporate the stakeholders into the decision-making process for a better governance $[22,89]$. In step 6 , it is expected that representatives of the mapped 
stakeholders' groups have regular meetings. It could include interactive workshops (group learning, discussion of the current state, and strategies and pathways, as proposed by Iwaniec et al. [90]). In these collaborative meetings, the stakeholders could provide practical recommendations for overcoming some of the barriers to planning and implementation of resource recovery target solutions [91].

Results from Laura et al. [22] corroborate with our findings regarding the lack of contact among the stakeholder's groups. For instance, WWTP managers and local authorities have very little collaboration with scientific experts and negligible relationships with NGOs, causing an absence of technical support to WWTP. Some measures to address this barrier are visits to universities for demonstration of technologies/studies related to resource recovery, pilot-scale projects in WTTP to increase the collaboration with research universities, benchmarking of successful operational practices in other contexts, and the regular stakeholders' meetings (as suggested previously).

\subsubsection{Steps 7 to 9-Comparison between Resource Recovery Technologies Options}

Previous steps of the framework assisted decision-making about which resource is worth being recovered. Based on this diagnosis (steps 1 to 6), the energy recovery and sludge management (e.g., nutrient recycling) seem to have higher potential and to be priorities according to consulted regional planning documents, and based on a previous study [31], when these options were reported as an area of interest by plant managers. The choice of recovery technologies considered the existing technology set-up in the plant, the level of development of the technology, and the availability of a thorough data basis for analysis. Only processes at full-scale (reported in the literature) were considered.

The scenario evaluation captured the necessary infrastructure updates, operational changes, and reuse applications [92]. Our purpose was not to produce an exhaustive evaluation of all possible technological alternatives that could be employed to recover resources. Instead, we focused on the most appropriated ones based on the previous steps of the framework and on previous literature.

The evaluated scenarios are listed as follows (Table 6):

A: Struvite production from supernatant obtained from thickeners and digesters, and sludge dewatering centrate. Crystallization of struvite with magnesium $(\mathrm{Mg})$ and $\mathrm{pH}$ increase via $\mathrm{NaOH}$ (sodium hydroxide). Examples: Fluidized bed reactor Pearl ${ }^{\circledR}$, Struvia ${ }^{\circledR}$, and others.

B: Organic fertilizer and soil conditioner production from windrow co-composting of dewatered sludge. Pre-treatment by mixing different types of wastes (e.g., sawdust/wood chips, chopped urban pruning, sugarcane bagasse, and eucalyptus husk) to achieve the $\mathrm{C} / \mathrm{N}$ ratio of 20:1 to 30:1 $[93,94]$. During composting, the temperature of sludge rises to about $50-60{ }^{\circ} \mathrm{C}$, which reduces the pathogen content. After composting, screening using sieves.

C: $\quad$ Energy recovery from biogas of anaerobic digesters. Co-digestion with food waste from street markets. Optimum temperature: $35-36{ }^{\circ} \mathrm{C}[95,96]$. Otto cycle engine to generate electricity [97].

D: Energy recovery by co-processing of sludge as raw material and fuel in kilns for cement industry. Pre-treatment for extra drying of sewage sludge (e.g., fluidized bed dryers and rotary dryers, solar drying, or by recovering residual heat from the cement kiln) until moisture content is less than $30 \%-25 \%$ [98-100]. The sewage sludge should be fed to a kiln system from the main burner, kiln inlet, or pre-calciner [99]. 
Table 6. Assessment of the recovery technology options against the indicators (step 9 of the framework). Further explanations are in Supplementary Material 3 (SM3). [102-152].

\begin{tabular}{|c|c|c|c|c|}
\hline \multirow[b]{2}{*}{$\begin{array}{c}\text { Indicator } \\
\text { Technical and Environmental }\end{array}$} & \multicolumn{4}{|c|}{ Resource Recovery Technology Options } \\
\hline & $\begin{array}{l}\text { A. Phosphorus (Struvite } \\
\text { Recovery) }\end{array}$ & $\begin{array}{l}\text { B. Nutrients and Organic Matter (Sewage } \\
\text { Sludge Co-composting) }\end{array}$ & $\begin{array}{l}\text { C. Energy (Biogas from Co-digestion } \\
\text { with Food Waste) }\end{array}$ & $\begin{array}{l}\text { D. Energy (Co-processing of Sludge } \\
\text { in Cement Industries) }\end{array}$ \\
\hline Recovery potential & $\begin{array}{c}10 \%-40 \% \text { from WWTP influent } \\
\mathrm{P} \text { and } 85 \%-95 \% \text { of } \mathrm{P} \text { input of the } \\
\text { recovery process } \\
\text { Estimate for the studied plant }{ }^{2}: \\
\text { About } 532.6 \mathrm{~kg} \text { of P/day (in } \\
\text { struvite) }\end{array}$ & $\begin{array}{l}\text { Organic matter content in dewatered sewage } \\
\text { sludge }(50 \%-70 \%), \mathrm{N}(3.4 \%-4 \%), \mathrm{P} \\
(0.5 \%-2.5 \%) \text { and micronutrients [118-120]. } \\
\text { Compost composition: organic carbon } 224.5, \\
\text { P 16.7, TKN 28.1 (g/Kg) [121]. Estimate: } 2.02 \\
\text { ton P/day in the dewatered sludge } 11\end{array}$ & $\begin{array}{l}\text { Co-digestion (an increase of } 20 \% \text { of organic } \\
\text { loading rate) causes an increase of } \\
21 \%-50 \% \text { of methane yield compared to } \\
\text { sewage sludge mono-digestion [95,130]. } \\
\text { Current methane production: } 2118.8 \\
\mathrm{Nm}^{3} / \text { day; with co-digestion: } 2565.9-3178.2 \\
\text { Nm } 3 \text { day. Estimated electric power: } \\
\text { 8877.7-10,996.4 kWh/day }{ }^{13}\end{array}$ & $\begin{array}{c}\text { Typical higher heating value (energy } \\
\text { content) of dried sewage sludge is } \\
11.10-22.10 \mathrm{MJ} / \mathrm{Kg} \text { (mean value: 16.05) } \\
\text { [141]. } \\
\text { Estimate for the studied plant: } \\
\text { 599,786.9MJ/day (thermal energy } \\
\text { recovered) [11] }\end{array}$ \\
\hline Technology maturity & $\begin{array}{l}\text { Full-scale, but TRL } 5 \text { in Brazil }{ }^{3} \\
{[15,107]}\end{array}$ & $\begin{array}{l}\text { Full-scale, similar initiative already taking } \\
\text { place in Brazil (TRL 9) }\end{array}$ & $\begin{array}{l}\text { Full-scale biogas recovery initiatives } \\
\text { already take place in Brazil, including one } \\
\text { plant with co-digestion in Paraná state } \\
\left(20,000 \mathrm{~m}^{3} \text { of biogas/day) (TRL 9) [131] }\right.\end{array}$ & $\begin{array}{l}\text { Full-scale, few applied in Brazil (sewage } \\
\text { sludge corresponds to } 0.4 \% \text { of the total } \\
\text { amount of co-processed wastes by } \\
\text { cement companies in Brazil) [142] (TRL 9) }\end{array}$ \\
\hline $\begin{array}{l}\text { Resource utilization (e.g., } \\
\text { energy } \\
\text { and chemical consumption) }\end{array}$ & $\begin{array}{c}\text { Electricity: } 4.9-6.6 \mathrm{kWh} / \mathrm{kg} \mathrm{P} \\
\text { rec., reactants consumption: } \\
\mathrm{MgCl}_{2}{ }^{*} 6 \mathrm{H}_{2} \mathrm{O} 7.7-8.5 \mathrm{~kg} / \mathrm{kg} \mathrm{P} \\
\text { rec. and } \mathrm{NaOH}: 0.2-0.22 \mathrm{~kg} / \mathrm{kg} \\
\text { P rec. }{ }^{4}[103]\end{array}$ & $\begin{array}{l}\text { Low energy demand and low demand for } \\
\text { reagents for composting (it may require } \\
\text { micronutrient addition and additives to the } \\
\text { product) [22] }\end{array}$ & $\begin{array}{l}\text { Electricity consumption for pre-treatment: } \\
35 \mathrm{kWh} \text { per ton of organic waste [132]. } \\
\text { Electricity consumed by Otto cycle engine: } \\
2 \% \text { of the total generated (up to } 219.9 \\
\mathrm{kWh} / \mathrm{day} \text { ) [133]. } \\
\text { Water consumption: } 0.37 \mathrm{~m}^{3} \text { per ton of } \\
\text { waste (in pre-treatment) [134] }\end{array}$ & $\begin{array}{l}\text { Energy consumption for sewage sludge } \\
\text { drying: } 30 \text { to } 1400 \mathrm{kWh} \text { per ton of } \\
\text { evaporated water (depends on the } \\
\text { process) [143,144]. Estimate for the } \\
\text { studied plant: } 34,577.88 \mathrm{kWh} / \text { day [11] }\end{array}$ \\
\hline $\begin{array}{l}\text { Quality of effluent and sludge } \\
\text { (removal of pollutants) and } \\
\text { environmental concern }\end{array}$ & $\begin{array}{l}\text { Low concentrations of } \\
\text { phosphate and ammonia in the } \\
\text { final effluent, } P \text { concentration in } \\
\text { final effluent (around } 0.4 \mathrm{mg} / \mathrm{L} \text { ) } \\
5[110] \text {, reduced energy demand } \\
\text { (for returning side-streams } \\
\text { flows and for aeration } \\
\text { [101,103]), no need for } \\
\text { reduction of heavy metals, and } \\
\text { no organic micropollutants in } \\
\text { the product, less production of } \\
\text { surplus sludge [111,112] }\end{array}$ & $\begin{array}{l}\text { Biosolids' land application avoids excess } \\
\text { nutrients entering the environment because } \\
\text { of their low nutrient contents compared with } \\
\text { fossil fuel-based fertilizers [12], global } \\
\text { warming impact is reduced [122], presence of } \\
\text { heavy metals and persistent pollutants in the } \\
\text { sludge and compost should be investigated } \\
\text { [123], low gas emissions, possible generation } \\
\text { of leachate [22,124] }\end{array}$ & $\begin{array}{l}\text { Reduction of greenhouse gas emissions } \\
\text { (52.4\%-63.2\% } \mathrm{kgCO} \mathrm{gC}_{2} \text { eq. per ton of waste } \\
\text { and sludge) when comparing with } \\
\text { digesting sewage sludge as single feedstock } \\
\text { [134]. Considering a WWTP with a scale } \\
\text { similar to the studied plant }\left(2.29 \mathrm{~m}^{3} / \mathrm{s}\right), \\
\text { biogas recovery would provide a reduction } \\
\text { of } 146.1 \text { tons of } \mathrm{CO}_{2} \text { eq./month [137]. } \\
\text { The digestate could be used in agriculture }\end{array}$ & $\begin{array}{l}\text { Release of contaminant gases [141]; no } \\
\text { need of specific treatment for ashes [99]; } \\
\text { significant reduction in sludge volume to } \\
\text { be disposed of; replacement of fossil fuels; } \\
\text { the ashes recovery causes a reduction of } \\
\text { use of raw material [145]; reduction in } \\
\text { greenhouse gas emissions; lower } \\
\text { emissions of } \mathrm{CO}_{2} \text { and NOx [146,147] }\end{array}$ \\
\hline
\end{tabular}


Table 6. Cont

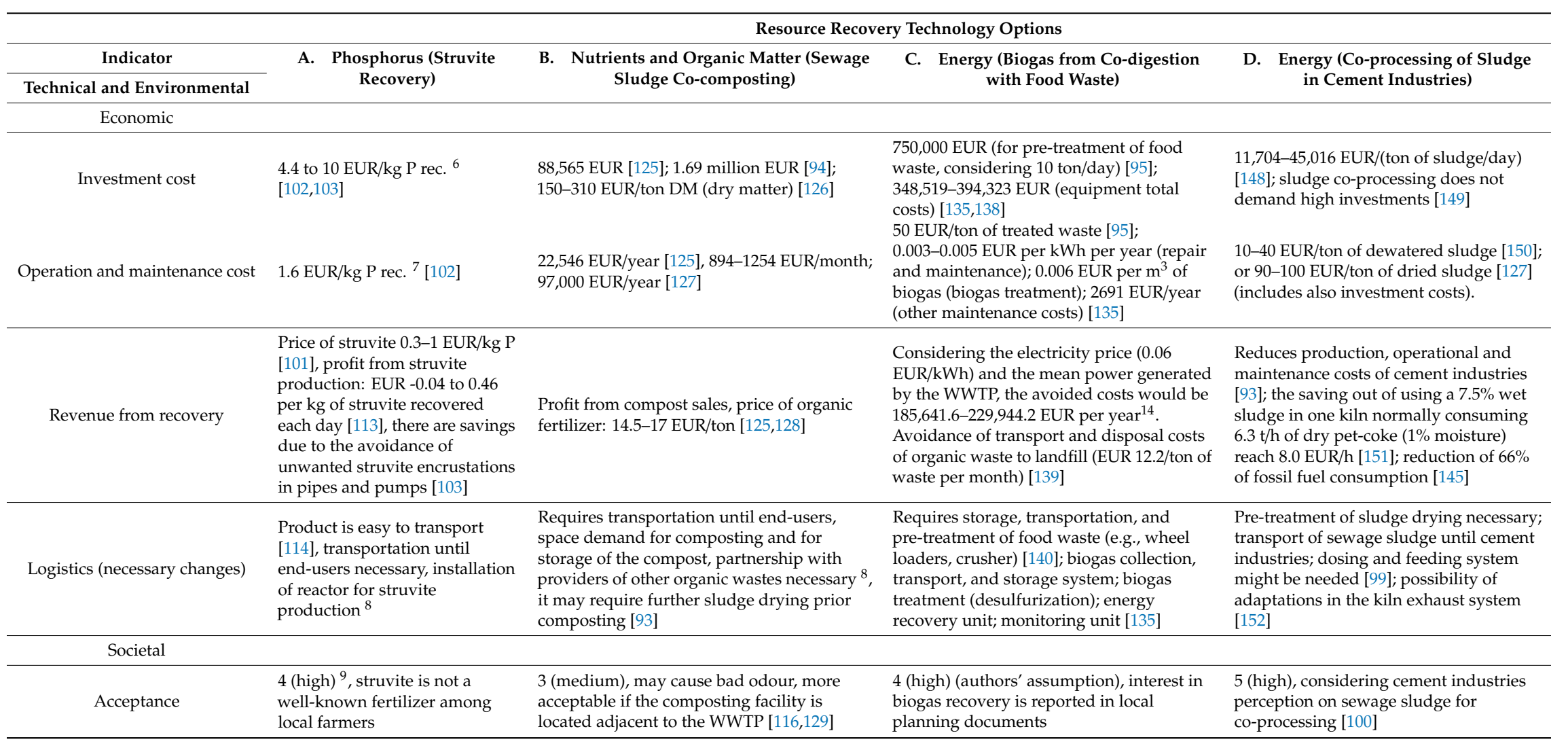


Table 6. Cont

\begin{tabular}{|c|c|c|c|c|}
\hline & \multicolumn{4}{|c|}{ Resource Recovery Technology Options } \\
\hline \multicolumn{5}{|l|}{ Institutional and political } \\
\hline $\begin{array}{l}\text { Accordance with policies and } \\
\text { legal requirements }\end{array}$ & $\begin{array}{l}\text { Possible, but national legislation } \\
\text { (e.g., quality criteria of the } \\
\text { product) needs to be developed } \\
\text { to facilitate struvite recovery } \\
\text { options }{ }^{10}\end{array}$ & $\begin{array}{l}\text { Yes, there are sufficient regulations and } \\
\text { policies } 10\end{array}$ & $\begin{array}{l}\text { Yes, there are sufficient regulations and } \\
\text { policies, and incentives (tax deductions) to } \\
\text { utilities that recover biogas }{ }^{10}\end{array}$ & $\begin{array}{l}\text { Yes, there are national and state } \\
\text { legislations that regulate co-processing in } \\
\text { general }{ }^{10}\end{array}$ \\
\hline \multicolumn{5}{|c|}{ 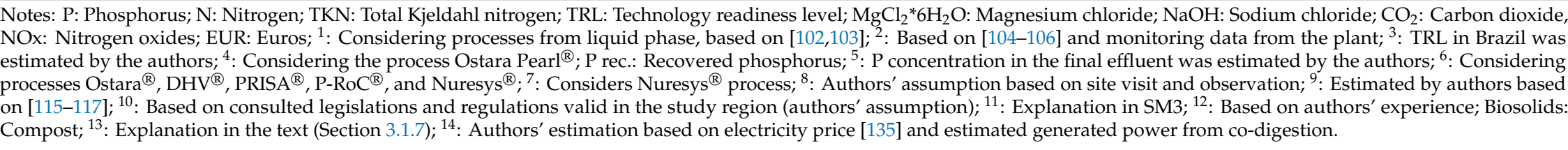 } \\
\hline
\end{tabular}


Technologies for P recovery based on sludge ashes were not included among the scenarios, because the plant does not perform sludge incineration and it is not a common route in Brazil (for municipal sewage sludge). The existing sludge disposal route in the plant is an important variable that influences the cost [101].

Existing P recovery techniques (e.g., struvite crystallization) are economically feasible with high $\mathrm{P}$ concentration streams (>50 mg-P/L), such as sludge liquors obtained from anaerobic digestion [153,154]. The recovery potential of struvite was estimated for the case study. Based on Jansen et al. [104], it was estimated that the thickeners' supernatant flow corresponded to $1 \%-2 \%$ of the raw wastewater flow, which approximately equaled to $35.1 \mathrm{~L} / \mathrm{s}$. The digester supernatant flow was around $29.23 \mathrm{~L} / \mathrm{s}(0.5 \%-2 \%$ of raw wastewater flow), and the reject water from dewatering was $8.2 \mathrm{~L} / \mathrm{s}$. These side streams could be directed to a reactor for $\mathrm{P}$ recovery-precipitation, and about $10 \%-40 \%$ of $\mathrm{P}$ in the raw wastewater could be recovered [104]. There were no data for P concentration in the digester supernatant for our case study, but according to literature, sludge liquor (thickener supernatant, dewatering centrate, and the anaerobic digestion side streams) had total P concentrations between 110 and $289 \mathrm{mg} / \mathrm{L}[105,106]$. Considering the flow of the P-enriched streams (72.53 L/s), a mean P concentration (100 mg/L), and the average rate of recovery of $85 \%$ from $\mathrm{P}$ influent (supernatant), the estimated $\mathrm{P}$ recovered would be $532.6 \mathrm{~kg} /$ day in the studied plant. This value would be enough to meet the annual fertilizer demand $\left(\mathrm{P}_{2} \mathrm{O}_{5}\right)$ in the study area (Table 5).

However, for the removal of lower P concentrations, both operational and investment costs would be higher [102]. The studied WWTP does not have enhanced biological phosphorus removal (EBPR); thus, it could be a limitation for struvite recovery processes from the liquid phase [106]. The polyphosphate contained in P-accumulating organisms (PAOs) can be released as orthophosphate when EBPR sludge is digested [155], facilitating struvite recovery [156]. By combining EBPR and P precipitation, a great percentage of $P$ in solution could be recovered as struvite [157]. If the studied plant applied EBPR, the P content in sludge would increase, consequently allowing for a higher recovery.

Regarding scenario B, a previous study [158] in another WWTP in Brazil showed that the composting process was enough to produce a compost that complied with the national quality standards (from the National Environmental Council) for heavy metals and pathogens. Thus, we expect that the composting scenario will be suitable to meet the quality requirements, but further regular analyses of the sewage sludge composition for the studied plant are necessary. A recent study by Nascimento et al. [51] investigated the quality of dewatered sludge generated in several plants in São Paulo state and assessed the suitability of the sludges for agricultural applications. Considering the results for São Paulo megacity plants, all sludge samples complied with the threshold values from CONAMA standards (National Environmental Council [81]), except for samples from two plants where Zn exceeded the maximum permitted. The authors considered the sludge promising as agricultural correctives to soils due to their high $\mathrm{pH}$ and micronutrient contents (Fe, $\mathrm{Zn}$, and $\mathrm{Mn}$ ). Regarding organic contaminants (e.g., pharmaceuticals and persistent organic pollutants) in sewage sludge, in Brazil, this research field is incipient so far. Souza et al. [123] evaluated aromatic polycyclic hydrocarbons (APH) in sewage sludge in Porto Alegre (Brazil) and found that the concentration was lower than the limits established by the European Union for APH. Another study [159] showed degradation of antibiotics during co-composting of sewage sludge with vegetable wastes (in Morocco).

Co-digestion with fruit and vegetable wastes was chosen for scenario $C$ because it can improve biogas yield [160]. In addition, anaerobic sludge digesters are usually oversized due to low organic sludge loading, indicating capacity to receive other substrates, enabling co-digestion [97,161]. Considering methane production, the lower calorific value of methane (9.97 kWh.Nm-3CH4) [139], and assuming an electric conversion efficiency of 38\% [135], the generator power capacity would be $405-501.7 \mathrm{~kW}$. In addition, considering 8000 operating hours per annum by the motor-generator $[135,162]$, the annual and daily power generation capacities were estimated (Supplementary Material S3 and Table 6). 
A low temperature in digesters $\left(22^{\circ} \mathrm{C}\right)$ was noted for our case study. Thus, the following improvements in operation conditions were suggested: The increase of temperature of digesters, and frequent measurement of biogas flow and its composition. These matters (digesters operation) are currently under consideration by SABESP (wastewater treatment company). It is also possible to suggest the implementation of a co-generation system to recover thermal energy from exhaust gases of the engine for heating the digesters, which would increase the efficiency of the process [163].

For scenario D, the following aspects should be considered. The dewatered sludge in the studied plant contained humidity between $60.6 \%$ and $74.5 \%$; thus, it would be necessary to dry the sludge before forwarding it to cement industries. Supplementary Material S2H contains some drying options. Another relevant aspect when exploring sewage sludge as fuel for co-processing is the proximity between the WWTP and cement industries. There are cement industries across the state of São Paulo, which makes it a possible alternative. However, in Brazil, fossil fuels represent $82 \%$ of calorific value in cement industries [142], and the use of sewage sludge for co-processing is irrelevant, being just some tests until the present moment. Sewage sludge corresponded to $0.4 \%$ of the total amount of co-processed wastes by cement companies in Brazil [142]. However, it is expected that it will increase significantly, particularly in south-eastern and southern regions in 2030 [164].

In developing countries, the most common routes for sludge disposal are landfilling and agricultural application [27]. These countries usually have little or no waste management infrastructure; therefore, properly controlled co-processing can be a practical, cost-effective, and more sustainable option instead of landfill and incineration [165]. In the metropolitan region of São Paulo, the sewage sludge is disposed in landfill [31]. In the studied plant, 113 tons of dewatered sludge was produced per day. Thus, scenarios B and D represent promising sustainable solutions to sewage sludge management.

Based on their quality, the fertilizer or soil conditioner products (scenarios A and B) could be used for several applications such as landscaping in agriculture to restore degraded land or to cultivate crops, especially sugarcane, eucalyptus, ornamental plants, and in some cases, coffee and vegetables, following the existing standards (step 5). The electricity produced by scenario $C$ would be used to supply part of the internal demand in the WWTP (about 10\%-13\% of the total electricity consumed daily). For scenario $D$, the recovered energy would be used by cement industries. Considering two cement industries with kilns for clinker production (about 134 and $115 \mathrm{~km}$ of the WWTP ABC) [166], the thermal energy recovered by scenario D could meet about $2.3 \%$ of its total thermal energy demand annually (Supplementary Material S2H).

Social acceptance depends on the context and issues can be more critical for facilities in a densely populated region rather than in a nearly inhabited area [150]. One of the most influential factors associated with public acceptance in wastewater sector is the level of contact [167]. For scenarios C and D (energy recovery), the social acceptance is not truly relevant since these solutions do not directly affect the local population (no contact). Differently, the acceptance of plant managers and cement industries for these options could be aspects for further investigation.

In addition, concerns about environmental risks and human health associated with resource recovery measures can affect acceptance. For struvite recovery in agriculture, low acceptance can be attributed to low environmental awareness, lack of knowledge of public, and few scientific studies on this topic [168]. Until the present moment, struvite granules have been unknown by local fertilizers consumers in the São Paulo metropolitan region [18].

Regarding acceptance of compost from sewage sludge, there is a positive example in Jundiai city (60 km from São Paulo city) where the acceptance of the product is very good, and it does not represent a barrier. According to the technical director, responsible for composting facility, they have not done any prior acceptance studies, but they conducted initiatives such as promotion of visits to their plant, lectures, dissemination of information, sales offers, and participation in events with farmers. There was no resistance to the use of the product due to its origin (sewage sludge as raw material). The quality of the produced compost meets the standards (e.g., heavy metal concentration and pathogens-thermotolerant coliforms, Salmonella sp., and helminth eggs) [128]. In our scenario B, 
the composting plant could be built inside the WWTP area to reduce transportation costs, then only the compost volume (final product) would have to be transported.

As addressed in Table 6, all scenarios require further changes and demand necessary training for operators of the recovery processes. Further aspects that contribute to a better decision on recovery strategies are analysis of the final products and estimation of the market size [126]. However, concerning the economic indicators, cost calculations and estimates related to recovery processes are challenging, since there is no market for the recovered products in some cases. Indeed, the development of the market can occur in parallel to the implementation of resource recovery solutions in the WWTP.

The selected example WWTP already performs water reuse. Thus, in the future, other measures that could take place in parallel with the increase of its treatment capacity would be the expansion of water reuse for internal purposes, industrial supply and for other sectors such as irrigation, non-potable urban purposes, and for indirect potable reuse through discharging of the treated effluent in water reservoirs (of water supply systems).

The different scenarios (step 9) can provide new insights in the design of sustainable value chains. Delanka-Pedige et al. [169] have proposed the wastewater infrastructure attributes that support sustainability: Reuse-quality of water recovered from wastewater; safe pathogen reduction from wastewater; energy use and recovery in wastewater treatment; biofertilizer recovery from wastewater; and emission (direct and indirect) reduction in wastewater treatment. The recovery scenarios proposed (Table 6), together with the existing water reuse practice contribute to sustainability in all these attributes.

The proposed framework supports the application of a circular economy at a regional level, through the integration of production and consumption systems. In practice, the success of a circular economy approach in the water and sanitation sector will depend on some factors such as partnerships among stakeholders, user engagement, and overcoming of existing barriers [170]. In this context, there is a need for tools that enable the translation of scientific results to create an evidence base that supports decision-makers to act $[171,172]$. The proposed framework can be an example of tools that fit to this purpose.

Considering all indicators (Table 6 and Figure 5) for the studied plant, scenario B seems to be the most favorable for nutrient recovery due to low costs, high recovery potential, and a lesser requirement for skilled labor. For energy recovery, biogas recovery seems more favorable considering the set of indicators. In terms of institutional and political indicator, the biogas recovery scenario is the most favorable.

\begin{tabular}{|c|c|c|c|c|c|}
\hline Category & Indicators & A & B & C & D \\
\hline \multirow{6}{*}{ Technical and Environmental } & Recovery potential & & & & \\
\hline & Technology maturity & & & & \\
\hline & Resource utilization & & & & \\
\hline & Need for additional skilled labour & & & & \\
\hline & Positive environmental effect & & & & \\
\hline & Quality of final product & & & & \\
\hline \multirow{4}{*}{ Economic } & Investment cost & & & & \\
\hline & Operation and maintenance cost & & & & \\
\hline & Revenue from recovery & & & & \\
\hline & Logistics & & & & \\
\hline Societal & Acceptance & & & & \\
\hline Institutional and political & Accordance to policies and legal requirements & & & & \\
\hline
\end{tabular}

Figure 5. Comparison of resource recovery scenarios. (A) Struvite recovery; (B) co-composting of sewage sludge; (C) biogas recovery from co-digestion; (D) energy recovery from co-processing of 
sewage sludge. Green corresponds to more favorable conditions, when the value of the attribute under evaluation is not problematic (it is considered positive); yellow represents intermediate situations; and red is used when the value of attribute raises a potential problem (it could represent a negative situation). Gray: Not applicable. More information on assessment and quantitative values are in SM4.

Steps 10 and 11 were not considered in this paper, since the resource recovery solution implementation was not part of this research, and decision-making depended on wastewater treatment plant managers' and local stakeholders' preferences. For instance, they could assign a high weight to one of the sets of indicators (e.g., economic or environmental), which would influence the final choice about the best solution among the defined scenarios [26]. Depending on stakeholders' and decision-makers' preferences, more than one scenario could be chosen, or they could be combined.

Overall, prior to a decision on implementation of any resource recovery technology (e.g., nutrient recovery), it is recommended that quantitative flows and qualitative data should be more thoroughly analyzed (e.g., nutrient content in the supernatants and in sludge, and other relevant parameters such as contaminants).

\subsection{Strengths and Potential Improvements of the Framework}

\subsubsection{Strengths of the Proposed Framework and Comparison with Similar Studies}

Some frameworks related to urban water management have been proposed and can play an important role to enable sustainability assessments, planning, and decision-making at different scales [173]. Frameworks can be useful to multiple purposes: To enable the diagnosis of a specific current situation, to be a management tool, to assess opportunities of improvement, and to facilitate stakeholder engagement and communication [173]. The framework tested in our study fits all these purposes.

Previous studies have developed frameworks for water reuse [21] and sludge management [22]. Papa et al. [21] developed a tool for evaluating the water reuse from technical and economic sustainability. Their framework aimed to judge the feasibility of wastewater reuse and considered the rating of the WWTP, hydraulic system (required for transportation), and the final user. The need for additional/polishing treatment of the effluent to satisfy quality criteria, and an increase of the costs (e.g., for plant upgrade, water distribution system, and the monitoring of reuse system) were considered as constraints to water reuse [21].

Laura et al. [22] created a framework to guide decision-making towards selecting sustainable options to handle sewage sludge. It included the evaluation of possible scenarios and considered four dimensions: Economic, environmental, social, and technical. Similarities with our study were the inclusion of stakeholder analysis (mapping), characterization data of sewage sludge, and analysis of local regulation.

O'Dwyer et al. [23] created a framework focusing on the optimization of design schemes of treatment plants and transport networks. In their assessment, environmental impacts and financial costs were considered for each scenario. Kehrein et al. [24] presented a framework for designing and planning of WWTP towards resource recovery activities. Some similarities compared to our framework are market analysis for recovered resources, inclusion of stakeholders, treatment performance analysis, and techno-economic and environmental assessment.

In our study, the proposed framework is not restricted to water reuse or sludge scenarios and serves for assessing other resource recovery measures, including more indicators and involving a variety of stakeholders. Thus, compared to previous developed frameworks, our framework is more comprehensive and offers descriptive instructions on how to approach each step. Another highlight is the final step of implementation and monitoring, which allows to optimize the recovery process and/or restart the framework application to combine with other resource recovery solutions.

One advantage of the proposed framework is that it could be easily presented to third parties with no specific technical background. Operationalization of the framework may be complicated and 
complex especially in data-scarce regions, but applying the framework in a collaborative way with key stakeholders (representatives of different groups/sectors) could facilitate the process and contribute to an increase in managers' and policy-makers' understanding of the subject (resource recovery).

Planning in the sanitation sector in developing countries should consider a multi-sectoral approach recognizing the interrelations between sanitation and other sectors such as water supply and solid waste management [174]. Van der Kooij et al. [17] highlighted the importance of making connections between wastewater treatment systems, agri-food systems, and ecological aspects to find more suitable recovery options. In our study, the application of the framework allowed us to identify these interactions and contributed to a better knowledge on recovery options.

Our framework aimed to capture context-specific characteristics to make a better decision. This addressed the future research needed mentioned by Diaz-Elsayed et al. [7] about the analysis of demand for resources and potential resources that can be recovered within design and local conditions. By applying our framework, it would be possible to identify potential challenges in the selection and implementation of resource recovery process configurations (e.g., water, energy, and nutrients), and as an additional step it was possible to restart the framework application (from step 7) to combine technologies to recover different resources. This should facilitate decision-making on integrated resource recovery since the previous steps were already concluded. Thus, the new framework had a practical value and allowed for plant managers to think about new potential solutions by providing relevant information. The proposed framework could also be complementary to the City Blueprint Framework, which is a tool that evaluates urban water management in a city [33].

\subsubsection{Practical Challenges as well as Future Directions and Perspectives}

After testing the framework with the case study, suggestions for improvements were evaluated. Step 7 (the choice of resource to be recovered) could be placed before step 6 . Then, based on the target resource potential, key stakeholders could be mapped. This could make conducting step 6 easier and quicker; i.e., narrow down the number of stakeholders. Other suggestions for future applications of the framework were to limit the scale of analysis, for instance, to a smaller geographical area (at a city level or a neighborhood), or to a specific sector as an end-user (industry or agriculture). We believe that it could reduce the complexity of analysis and reduce the amount of data required, and, consequently, the challenges related to data collection and availability, despite losing the holistic perception of recovery alternatives and the view of the interactions at different scales.

Another possibility could be to start the framework application at step 6 (identifying stakeholders), particularly for contexts and places where data are scarce. It would likely facilitate (reduce time demand) the process to gather data needed for applying the other steps of the framework. For instance, if stakeholders from a local environmental agency/government were involved from the beginning, they could assist in the identification of the relevant legal and regulatory frameworks.

In this study, the authors considered the application of the framework for recovering of water, energy, and nutrients, although it is highlighted that the framework could be adapted for application even in different contexts (e.g., WWTP in urban or rural areas) and for other target resources.

The planning process requires detailed and accurate data and information. In step 9, in order to perform more accurate evaluations, it is recommended to replace qualitative limits by quantitative values as mentioned by a previous study [22]. This could be done in future studies, depending on data availability.

\subsection{Limitations}

The presented findings captured only a snapshot in time, conveying the current developments of recovery technologies and providing the framework application considering the data collected during a specific period. But the study region is very dynamic. Therefore, some aspects and data continually change in short or long terms (e.g., price of recovery technology, demand, and regulations), and the analysis through the proposed framework should be updated or restarted. According to Van der Hoek 
et al. [14], many external factors may change over time due to technological, environmental, economic, and market developments, and these uncertainties can influence the possibilities of resource recovery implementation. Other limitations noticed during application of the proposed framework was the lack of availability of some input data (e.g., some parameter concentration of treated effluent and sludge composition data, and costs for struvite precipitation in the Brazilian context).

Finally, we would like to emphasize that integrated evaluations at large-scale are characterized by a high degree of complexity (as mentioned by Papa et al. [21]). This was the case for our study, because we considered a large area, and the steps of the framework considered several types of data. The results of framework application depend on the overall availability of input data. Therefore, it highlights the need for improvement of monitoring practices either in a wastewater treatment plant or beyond (in other sectors; for example, water consumption in urban uses). There is uncertainty associated with secondary data used in the framework. For instance, although we considered the most updated available data, in some cases, they came from various sources.

\section{Conclusions and Recommendations}

Through the framework application, local context was deeply analyzed and the demand for water, energy, and $\mathrm{P}$ was identified. Some scenarios were recommended, and opportunities for improvement of existing processes were proposed.

Based on the results, all scenarios could be feasible for the studied WWTP, especially biogas recovery from co-digestion and sludge co-composting considering all the technical, environmental, societal, and political/institutional indicators. Local legislations seem to be favorable to implementation in all scenarios, except for struvite recovery, which needs further development. In addition, we recommend tests at pilot scale in the study region before applying struvite at full-scale WWTP. The suggested scenarios have potential to provide environmental benefits such as improvement of effluent quality (scenario A), low $\mathrm{CO}_{2}$ emissions, reduction in global warming potential, and reduction of waste generation (scenarios $\mathrm{B}, \mathrm{C}$, and $\mathrm{D}$ ).

With increasing demands for water, energy and food, particularly in urban areas, recovering resources from sewage is an important strategy. Considering only one WWTP in São Paulo megacity, the authors showed there is a potential to meet all the current demand for phosphorus fertilizer and non-potable water (main industries and agriculture) in the study region. Therefore, in quantitative terms, water reuse from the treated effluent could meet the current water demand for industrial and agricultural uses; and $\mathrm{P}$ recovery potentials from recovery scenarios could supply all the current demand for phosphate fertilizer in agriculture in the study region.

In summary, the strengths of the proposed framework are addressing the complexities of dynamic systems and integrating with relevant sectors and stakeholders, while the main limitations include the need of some data, which may not be available. The methodology used in this paper might be applied to other contexts, and the data from the case study (effluent and by-product characterization and potential demand) could be compared to other studies/regions. In addition, the comparison of recovery scenarios based on indicators and literature (Table 6) can be used as a basis for further studies under the circular economy perspective.

This paper provided a simple tool as a structuring mechanism to support resource recovery implementation from wastewater treatment, which is useful to managers and decision-makers. The results can help the elaboration of resource recovery projects. The framework refinement and use (presented here) can guide potential applications in other contexts.

In future studies, as soon as the market for recovered products develops, it is possible to calculate economic indicators using detailed local prices, and the social acceptance evaluation after consulting stakeholders and survey with the local community. Further studies could also explore stakeholder engagement and cooperation during framework application. Other relevant and necessary themes are the monitoring of sludge quality, removal of persistent organic pollutants in sewage sludge composting, analysis of risks to environment and human health from its application in soil, monitoring of $\mathrm{P}$ in 
reject water (thickeners, digester supernatants and dewatering centrate), development of local business models for resource recovery, multi-sectoral engagement approaches, and testing of the framework application in other cities.

Supplementary Materials: The following are available online at http://www.mdpi.com/2073-4441/12/12/3466/s1, Supplementary Materials S1-4. Supplementary Material S1: List of data collected for the wastewater treatment plant; Supplementary Material S2 (2A-H): Further information concerning framework application; Supplementary Material S3: Further explanation regarding Table 6; Supplementary Material S4: Further explanation to Figure 5. References [175-210] are cited in the Supplementary Materials S2 to S4.

Author Contributions: Conceptualization, M.C.C., M.S., M.A.N.; methodology, M.C.C.; formal analysis, M.C.C.; investigation, M.C.C., F.d.M.d.S.; data curation, M.C.C., F.d.M.d.S.; writing-original draft preparation, M.C.C.; writing-review and editing, M.C.C., F.d.M.d.S., M.S., M.A.N.; visualization, M.C.C.; supervision, M.S., M.A.N. All authors have read and agreed to the published version of the manuscript.

Funding: This study was funded by the Coordenação de Aperfeiçoamento de Pessoal de Nível Superior (Brazilian Federal Agency for Support and Evaluation of Graduate Education), Brazil (CAPES), finance code 001, through a scholarship granted to the double degree doctoral student Mariana Cardoso Chrispim.

Acknowledgments: The authors thank the staff of SABESP (water and sanitation company) for kindly providing the requested data about the studied wastewater treatment plant. We acknowledge the support received from local experts concerning the selected megacities for their contribution by providing related data. We are also grateful to the student Karla Mesquita for assisting in part of the data collection (and the scientific initiation scholarship from Cnpq).

Conflicts of Interest: The authors declare no conflict of interest. The funders had no role in the design of the study; in the collection, analyses, or interpretation of data; in the writing of the manuscript; or in the decision to publish the results.

\section{References}

1. Bressani-Ribeiro, T.; Mota Filho, C.R.; de Melo, V.R.; Bianchetti, F.J.; de Lemos Chernicharo, C.A. Planning for achieving low carbon and integrated resources recovery from sewage treatment plants in Minas Gerais, Brazil. J. Environ. Manag. 2019, 242, 465-473. [CrossRef]

2. Zhang, P.; Zhang, L.; Chang, Y.; Xu, M.; Hao, Y.; Liang, S.; Liu, G.; Yang, Z.; Wang, C. Food-energy-water (FEW) nexus for urban sustainability: A comprehensive review. Resour. Conserv. Recycl. 2019, 142, $215-224$. [CrossRef]

3. United Nations. Goal 11: Sustainable Development Knowledge Platform. 2016. Available online: https: //sustainabledevelopment.un.org/sdg11 (accessed on 10 September 2020).

4. Andersson, K.; Dickin, S.; Rosemarin, A. Towards "Sustainable" Sanitation: Challenges and Opportunities in Urban Areas. Sustainability 2016, 8, 1289. [CrossRef]

5. Zhang, Y.; Zhang, C.; Qiu, Y.; Li, B.; Pang, H.; Xue, Y.; Liu, Y.; Yuan, Z.; Huang, X. Wastewater treatment technology selection under various influent conditions and effluent standards based on life cycle assessment. Resour. Conserv. Recycl. 2020, 154, 104562. [CrossRef]

6. Boiocchi, R.; Matafome, B.; Gargalo, C.L.; Carvalho, A.; Sin, G. Techno-economic analysis of resource recovery technologies for wastewater treatment plants. Comput. Aided Chem. Eng. 2017, 40, 1945-1950. [CrossRef]

7. Diaz-Elsayed, N.; Rezaei, N.; Ndiaye, A.; Zhang, Q. Trends in the environmental and economic sustainability of wastewater-based resource recovery: A review. J. Clean. Prod. 2020, 265, 121598. [CrossRef]

8. Khan, M.Z.H.; Karim, M.R.; Haque, A.A.M.; Hossain, M.Z. Water supply and sanitation: For mega cities. In Proceedings of the Conference 5th International Symposium on New Technologies for Urban Safety of Mega Cities in Asia (USMCA), Phuket, Thailand, 10-12 February 2006.

9. Chen, Z.; Wu, Q.; Wu, G.; Hu, H.Y. Centralized water reuse system with multiple applications in urban areas: Lessons from China's experience. Resour. Conserv. Recycl. 2017, 117, 125-136. [CrossRef]

10. Kim, H.; Son, J.; Lee, S.; Koop, S.; van Leeuwen, K.; Choi, Y.; Park, J. Assessing Urban Water Management Sustainability of a Megacity: Case Study of Seoul, South Korea. Water 2018, 10, 682. [CrossRef]

11. Bouzas, A.; Martí, N.; Grau, S.; Barat, R.; Mangin, D.; Pastor, L. Implementation of a global P-recovery system in urban wastewater treatment plants. J. Clean. Prod. 2019, 227, 130-140. [CrossRef]

12. Mo, W.; Zhang, Q. Energy-nutrients-water nexus: Integrated resource recovery in municipal wastewater treatment plants. J. Environ. Manag. 2013, 127, 255-267. [CrossRef] 
13. Puchongkawarin, C.; Gomez-mont, C.; Stuckey, D.C.; Chachuat, B. Optimization-based methodology for the development of wastewater facilities for energy and nutrient recovery. Chemosphere 2015, 140, 150-158. [CrossRef]

14. Van Der Hoek, J.P.; De Fooij, H.; Struker, A. Wastewater as a resource: Strategies to recover resources from Amsterdam's wastewater. Resour. Conserv. Recycl. 2016, 113, 53-64. [CrossRef]

15. Chrispim, M.C.; Scholz, M.; Nolasco, M.A. Phosphorus recovery from municipal wastewater treatment: Critical review of challenges and opportunities for developing countries. J. Environ. Manag. 2019, 248, 109268. [CrossRef] [PubMed]

16. Sarvajayakesavalu, S.; Lu, Y.; Withers, P.J.A.; Pavinato, P.S.; Pan, G.; Chareonsudjai, P. Phosphorus recovery: A need for an integrated approach. Ecosyst. Health Sustain. 2018, 4, 48-57. [CrossRef]

17. Van der Kooij, S.; Van Vliet, B.J.M.; Stomph, T.J.; Sutton, N.B.; Anten, N.P.R.; Hoffland, E. Phosphorus recovered from human excreta: A socio-ecological-technical approach to phosphorus recycling. Resour. Conserv. Recycl. 2020, 157, 104744. [CrossRef]

18. Sánchez, A.S. Technical and economic feasibility of phosphorus recovery from wastewater in São Paulo's Metropolitan Region. J. Water Process. Eng. 2020, 38, 101537. [CrossRef]

19. Wilcox, J.; Nasiri, F.; Bell, S.; Rahaman, M.S. Urban water reuse: A triple bottom line assessment framework and review. Sustain. Cities Soc. 2016, 27, 448-456. [CrossRef]

20. Romeiko, X.X. Comprehensive water footprint assessment of conventional and four alternative resource recovery based wastewater service options. Resour. Conserv. Recycl. 2019, 151, 104458. [CrossRef]

21. Papa, M.; Bertanza, G.; Abbà, A. Reuse of wastewater: A feasible option, or not? A decision support system can solve the doubt. Desalin. Water Treat. 2016, 57, 8670-8682. [CrossRef]

22. Laura, F.; Tamara, A.; Müller, A.; Hiroshan, H.; Christina, D.; Serena, C. Selecting sustainable sewage sludge reuse options through a systematic assessment framework: Methodology and case study in Latin America. J. Clean. Prod. 2020, 242, 1-12. [CrossRef]

23. O’Dwyer, E.; Chen, K.; Wang, H.; Wang, A.; Shah, N.; Guo, M. Optimisation of wastewater treatment strategies in eco-industrial parks: Technology, location and transport. Chem. Eng. J. 2020, 381. [CrossRef]

24. Kehrein, P.; van Loosdrecht, M.; Osseweijer, P.; Garfí, M.; Dewulf, J.; Posada, J. The SPPD-WRF Framework: A Novel and Holistic Methodology for Strategical Planning and Process Design of Water Resource Factories. Sustainability 2020, 12, 4168. [CrossRef]

25. Thornberg, D.; Jorgensen, P. Working towards P-recovery from sludge ash in Copenhagen. In Proceedings of the IWA Sweden, BIOFOS, Malmö, Sweden, 11 April 2018; pp. 1-16.

26. Woltersdorf, L.; Zimmermann, M.; Deffner, J.; Gerlach, M.; Liehr, S. Benefits of an integrated water and nutrient reuse system for urban areas in semi-arid developing countries. Resour. Conserv. Recycl. 2018, 128, 382-393. [CrossRef]

27. Gallego-Schmid, A.; Tarpani, R.R.Z. Life cycle assessment of wastewater treatment in developing countries: A review. Water Res. 2019, 153, 63-79. [CrossRef]

28. Otoo, M.; Drechsel, P. Resource Recovery from Waste: Business Models for Energy, Nutrient and Water Reuse in Low- And Middle-Income Countries; Routledge: Abingdon, UK, 2018.

29. Cordell, D.; Rosemarin, A.; Schröder, J.J.; Smit, A.L. Towards global phosphorus security: A systems framework for phosphorus recovery and reuse options. Chemosphere 2011, 84, 747-758. [CrossRef]

30. Ma, X.C.; Xue, X.; González-Mejía, A.; Garland, J.; Cashdollar, J. Sustainable water systems for the city of tomorrow-A conceptual framework. Sustainability 2015, 7, 12071-12105. [CrossRef]

31. Chrispim, M.C.; Scholz, M.; Nolasco, M.A. A framework for resource recovery from wastewater treatment plants in megacities of developing countries. Environ. Res. 2020, 188, 109745. [CrossRef]

32. Arcadis. Sustainable Cities Water Index-Which Cities are Best Placed to Harness Water for Future Success? Available online: https:/www.arcadis.com/media/4/6/2/\%7B462EFA0A-4278-49DF-9943-C067182CA682\% 7DArcadisSustainableCitiesWaterIndex_003.pdf (accessed on 4 December 2020).

33. Feingold, D.; Koop, S.; van Leeuwen, K. The City Blueprint Approach: Urban Water Management and Governance in Cities in the U.S. Environ. Manag. 2018, 61, 9-23. [CrossRef]

34. SDEWES Centre. SDEWES Index. Available online: https://www.sdewes.org/sdewes_index.php (accessed on 4 December 2020).

35. United Nations. The World's Cities in 2018. Available online: https:/www.un.org/en/events/citiesday/assets/ pdf/the_worlds_cities_in_2018_data_booklet.pdf (accessed on 10 September 2019). 
36. Cornejo, P.K.; Zhang, Q.; Mihelcic, J.R. How Does Scale of Implementation Impact the Environmental Sustainability of Wastewater Treatment Integrated with Resource Recovery? Environ. Sci. Technol. 2016, 50, 6680-6689. [CrossRef]

37. Brunner, P.H.; Rechberger, H. Practical Handbook of Material Flow Analysis, 1st ed.; CRC Press: Boca Raton, FL, USA, 2004.

38. IBGE/SIDRA. Tabela 6778-Número de Estabelecimentos Agropecuários (Table 6778-Number of Agricultural Establishments). 2017. Available online: https://sidra.ibge.gov.br/tabela/6778\#resultado (accessed on 11 October 2019).

39. Ministério do Trabalho e Emprego (MTE) (Ministry of Labor and Employment). Cadastro Geral de Empregados e Desempregados-Perfil do Munícipio (General Register of Employed and Unemployed-Profile of the Municipality), 2019. Available online: http://bi.mte.gov.br/bgcaged/caged_ perfil_municipio/index.php (accessed on 12 October 2019).

40. Certi (Reference Center in Innovative Technologies). Planejamento e Modelagem do Parque Tecnológico de Santo André (Planning and Modeling of the Santo André Technology Park). Available online: http://www3.santoandre.sp.gov.br/parquetecnologico/wp-content/uploads/2019/08/CERTIEtapa-2-Ecossistema-ABC-compactado.pdf (accessed on 10 October 2019).

41. IBGE. Produto Interno Bruto dos Municípios-Tabelas 2010-2017 (Gross Domestic Product of Municipalities-Tables 2010-2017). Available online: https://www.ibge.gov.br/estatisticas-novoportal/ economicas/contas-nacionais/9088-produto-interno-bruto-dos-municipios.html?=\&t=resultados (accessed on 8 February 2019).

42. Xavier, M.L.P.; Souza, A.N.C.; Rodrigues, J.P.; Bresciani, L.P. O novo perfil econômico do Grande ABC (The new economic profile of the Great ABC Region). Rev. Organ. Contexto 2007, 6, 103-122.

43. Sao Paulo City Council. Cadastramento de Unidades Produtivas (Registration of Production Units). Available online: https://ligueospontos.prefeitura.sp.gov.br/agricultura-familiar/cadastro/ (accessed on 2 November 2019).

44. Caisan (Intersecretary Chamber of Food and Nutritional Security of São Paulo). 1o Plano Municipal de Segurança Alimentar e Nutricional (1st Municipal Food and Nutritional Security Plan). Available online: https:/www.prefeitura.sp.gov.br/cidade/secretarias/upload/trabalho/ PLAMSANVERSAOFINALcompleta.pdf.\%0A (accessed on 25 March 2020).

45. IBGE/SIDRA. Tabela 6953-Número de Estabelecimentos com Horticultura (Table 6953-Number of Establishments with Horticulture). Available online: https://sidra.ibge.gov.br/tabela/6953\#resultado\%0A (accessed on 20 November 2019).

46. Aquapolo. Sobre o Aquapolo (About Aquapolo). Available online: http://www.aquapolo.com.br/quemsomos/sobre-o-aquapolo/\%0A (accessed on 1 March 2018).

47. Hildebrand, A.; Silva, P.C. SABESP: Relatório de Sustentabilidade 2019 (2019 Sustainability Report). Available online: http://site.sabesp.com.br/site/uploads/file/relatorios_sustentabilidade/Relatorio_ Sustentabilidade_2019_port.pdf (accessed on 5 May 2020).

48. Borges, N.B. Aproveitamento dos Resíduos Gerados no Tratamento Preliminar de Estações de Tratamento de Esgoto (Utilization of the Waste Generated in the Preliminary Treatment of Sewage Treatment Plants). Ph.D. Thesis, University of São Paulo, São Carlos, Brazil, 2014.

49. Cornejo, P.K. Environmental Sustainability of Wastewater Treatment Plants Integrated with Resource Recovery: The Impact of Context and Scale. Ph. D. Thesis, University of South Florida, Tampa, FL, USA, 2015.

50. Mehta, C.M.; Khunjar, W.O.; Nguyen, V.; Tait, S.; Batstone, D.J. Technologies to Recover Nutrients from Waste Streams: A Critical Review. Crit. Rev. Environ. Sci. Technol. 2015, 45, 385-427. [CrossRef]

51. Nascimento, A.L.; de Souza, A.J.; Oliveira, F.C.; Coscione, A.R.; Viana, D.G.; Regitano, J.B. Chemical attributes of sewage sludges: Relationships to sources and treatments, and implications for sludge usage in agriculture. J. Clean. Prod. 2020, 258, 120746. [CrossRef]

52. Sun, Y.; Chen, Z.; Wu, G.; Wu, Q.; Zhang, F.; Niu, Z.; Hu, H. Characteristics of water quality of municipal wastewater treatment plants in China: Implications for resources utilization and management. J. Clean. Prod. 2016, 131, 1-9. [CrossRef] 
53. National Water Agency. Demanda Hídrica na Indústria de Transformação em 2015-Resultados por UF, Município e Tipologia Industrial-Planilha (Water Demand in the Manufacturing Industry in 2015-Results by FU, Municipality and Industrial Typology-Spreadsheet). Available online: https://metadados.ana.gov.br/geonetwork/srv/pt/main. home?uuid=c3cd1505-0a96-4b79-9604-4f69f8cec225\%0A (accessed on 10 December 2019).

54. National Water Agency. Atlas Irrigação: Uso da Água na Agricultura Irrigada. Demanda Hídrica por Tipologia, por Município e Unidade da Federação (Water use in Agriculture Irrigation. Water Demand per Typology, Municipality and Federation Unit). Available online: https://metadados.ana.gov.br/geonetwork/ srv/pt/main.home?uuid=c639ac44-8151-421d-a1ed-c333392d76a9\%0A (accessed on 30 November 2019).

55. Costa, E.F. Água de Reúso ETE (Reclaimed Water). Unpublished results. Sao Paulo, Brazil. Personal communication, 2019.

56. Secretary of Infrastructure and Environment. Consumo de Energia no Estado de São Paulo (Energy Consumption in the State of São Paulo). Available online: http://dadosenergeticos.energia.sp.gov.br/ Portalcev2/Municipios/ranking/index.html (accessed on 12 October 2019).

57. IBGE Indicadores de Desenvolvimento Sustentável: Tabela 768-Quantidade Comercializada de Fertilizantes por Área Plantada, Segundo o Tipo de Nutriente (Sustainable Development Indicators: Table 768-Amount of Fertilizers Traded by Planted Area, According to). Available online: https://sidra.ibge.gov.br/Tabela/768\%0A (accessed on 1 December 2019).

58. IBGE. Produção Agrícola Municipal: Tabela 770-Utilização de Fertilizantes por Unidade de Área por Tipo de Nutriente (Municipal Agricultural Production: Table 770—Use of Fertilizers Per Unit Area Per Type of Nutrient). Available online: https://www.ibge.gov.br/estatisticas-novoportal/economicas/contas-nacionais/ 9088-produto-interno-bruto-dos-municipios.html?=\&t=resultados\%0A (accessed on 2 August 2019).

59. IBGE. Produção Agrícola Municipal: Tabela 5457-Área Plantada ou Destinada à Colheita, Área Colhida, Quantidade Produzida, Rendimento Médio e Valor da Produção das Lavouras Temporárias e Permanentes (Municipal Agricultural Production: Table 5457-Area Planted). Available online: https://sidra.ibge.gov.br/ tabela/5457\%0A (accessed on 20 November 2019).

60. National Water Agency. Água na Indústria: Uso e Coeficientes Técnicos (Water in Industry: Use and Technical Coefficients). Available online: https://www.ana.gov.br/noticias/estudo-da-agencia-nacional-de-aguasaborda-uso-da-agua-no-setor-industrial/agua-na-industria-uso-e-coeficientes-tecnicos-versao-final.pdf (accessed on 12 May 2019).

61. Kollar, K.L.; Macauley, P. Water requirements for industrial development (USA). J. Am. Water Works Assoc. 1980, 71, 2-9. [CrossRef]

62. Federation of Industries of the State of São Paulo (FIESP). O Uso Racional da Água no Setor Industrial (Rational Water Use in Industrial Sector), 2nd ed.; Federation of Industries of the State of São Paulo, National Confederation of Industry: Brasilia, Brazil, 2017.

63. National Water Agency. Atlas Irrigação: Uso da Água na Agricultura Irrigada (Atlas Irrigation: Water Use in Irrigated Agriculture). Available online: https://arquivos.ana.gov.br/imprensa/publicacoes/AtlasIrrigacaoUsodaAguanaAgriculturaIrrigada.pdf (accessed on 12 May 2019).

64. SABESP. Conheça as Nossas Tarifas (Know our Rates-Sabesp). Available online: https://www9.sabesp.com. br/agenciavirtual/pages/template/siteexterno.iface?idFuncao=13\%0A (accessed on 20 December 2019).

65. IEA. Mercado de Fertilizantes (Fertilizer Market). Available online: http://www.iea.sp.gov.br/out/TerTexto. php?codTexto=14447\%0A (accessed on 13 November 2019).

66. Companhia Nacional de Abastecimento (National Company of Supply). Insumos Agropecuários (Agricultural Inputs). Available online: https://consultaweb.conab.gov.br/consultas/consultaInsumo.do? d-6983528-p=1\&uf=SP\&d-6983528-o=1\&ano=2019\&method=acaoListarConsulta\&idSubGrupo=71\& btnConsultar=Consultar\&jcaptcha $=$ rcu3\&d-6983528-s=1\&idGrupo=27 (accessed on 20 May 2005).

67. Ministry of Cities and IICA. Elaboração de Proposta do Plano de Ação Para Instituir Uma Política de Reúso de Efluente Sanitário Tratado no Brasil: Produto VI—Plano de Ações/Política de Reúso (RF) (Preparation of a Proposal for the Action Plan to Institute a Policy for the Reuse of). Available online: https://antigo.mdr.gov.br/images/stories/ArquivosSNSA/interaguas/reuso/produto4_ avaliacao_do_potencial_de_reuso.pdf (accessed on 4 December 2020).

68. Sao Paulo State Government. Resolução Conjunta SES/SMA/SSRH $n^{\circ} 1$ (Joint Resolution 01); Sao Paulo State Government: Sao Paulo, Brazil, 2017. 
69. Sao Paulo State Government. Resolução Conjunta SES/SIMA $n^{\circ} 1$ (Joint Resolution 01); Sao Paulo State Government: Sao Paulo, Brazil, 2020.

70. Sao Paulo State Government. Decreto $n^{\circ} 48.138$ (Decree No. 48138); Assembléia Legislativa do Estado de São Paulo: Sao Paulo Brazil, 2003.

71. Cetesb (Environmental Agency of the State of Sao Paulo).Orientação Para Apresentação de Projeto Visando a Aplicação de Água de Reuso Proveniente de Estação de Tratamento de Esgoto Doméstico na Agricultura (Guidance for Project Presentation Aiming at the Application of Reuse Water From Domestic Sewage Treatment Plant in Agriculture). 2006. Available online: https://cetesb.sp.gov.br/aguas-subterraneas/ publicacoes-e-relatorios/ (accessed on 20 February 2020).

72. Ministry of Cities and IICA. Elaboração de Proposta do Plano de Ação Para Instituir Uma Política de Reúso de Efluente Sanitário Tratado no Brasil: Produto III—Critérios de Qualidade da Água (RP01B) (Preparation of a Proposal for the Action Plan to Institute a Policy for the Reuse o). Available online: https:/arquivos.ana.gov.br/ interaguas/MCID_Reuso_Produto3-CriteriosdeQualidadedaAguadeReuso.pdf (accessed on 15 May 2020).

73. Sao Paulo State. Government Resolução SMA no 079 (Joint Resolution 079); Environmental State Secretariat: Sao Paulo, Brazil, 2009.

74. Brazil. Lei no. 9.427 (Law No. 9.427); Government of Brazil: Brasilia, Brazil, 1996.

75. PNUD and MMA. Produto 6-Resumo Executivo: Estudo Sobre o Potencial de Geração de Energia a partir de Resíduos de Saneamento (Lixo, Esgoto), Visando Incrementar o Uso de Biogás Como Fonte Alternativa de Energia Renovável (Product 6-Executive Summary: Study on the Potential for Energy Generation from Sanitation Waste (Garbage, Sewage), Aiming to Increase the Use of Biogas as an Alternative Source of Renewable Energy). [WWW Document]. 2010. Available online: https://www.mma.gov.br/estruturas/164/ _publicacao/164_publicacao10012011033201.pdf (accessed on 3 March 2020).

76. Agência Nacional de Energia Elétrica. Resolução Normativa $n^{\circ} 482$ (Joint Resolution 482); Agência Nacional de Energia Elétrica: Brasilia, Brazil, 2012.

77. Joppert, C.L.; Perecin, D.; Santos, M.M.; Coelho, S.T.; Camacho, J.L.P. A short-cut model for predicting biomethane availability after biogas upgrading. J. Clean. Prod. 2018, 200, 148-160. [CrossRef]

78. Sao Paulo State Government. Decreto $n^{\circ} 60.001$ (Decree No. 60001); Legislative Assembly of the State of Sao Paulo: Sao Paulo, Brazil, 2013.

79. Sao Paulo State Government. Decreto $n^{\circ} 60.298$ (Decree No. 60298); Legislative Assembly of the State of Sao Paulo: Sao Paulo, Brazil, 2014.

80. National Environment Council (CONAMA). Resolução CONAMA 498 (Regulation CONAMA 498); National Environment Council (CONAMA): Brasilia, Brazil, 2020.

81. National Environment Council (CONAMA). Resolução CONAMA 375 (Regulation CONAMA 375); National Environment Council (CONAMA): Brasilia, Brazil, 2006.

82. MAPA (Ministério da Agricultura, Pecuária e Abastecimento or Ministry of Agriculture, Livestock and Supply). Instrução Normativa $N^{\circ} 6$ (Normative Instruction No. 6); MAPA: Brasilia, Brazil, 2016.

83. Sao Paulo State Government. Lei $n^{\circ} 13.798$ (Law No. 13798); Sao Paulo State Government: Sao Paulo, Brazil, 2009.

84. Consórcio Intermunicipal Grande ABC (Intermunicipal Consortium Grande ABC). Plano de Ação de Enfrentamento às Mudanças Climáticas do Grande ABC (Greater ABC Climate Change Action Plan). 2017. Available online: http://consorcioabc.sp.gov.br/imagens/noticia/Plano $\% 20 \mathrm{de} \% 20 \mathrm{Acao} \% 20 \mathrm{de} \% 20$ Enfrentamento $\%$ 20as\%20Mudancas\%20Climaticas\%20do\%20Grande\%20ABC.pdf (accessed on 1 January 2020).

85. Sao Paulo. Plano Municipal de Saneamento Básico de São Paulo (Municipal Basic Sanitation Plan of São Paulo). 2019. Available online: https://gestaourbana.prefeitura.sp.gov.br/wp-content/uploads/2019/05/ PMSB_Caderno_Completo_-final-para-impressa\%CC\%83o.pdf (accessed on 2 May 2020).

86. SSWM (Sustainable Sanitation and Water Management Toolbox). Week 4: Analyse the Institutional Environment. 2019. Available online: https://sswm.info/iwmi-business-development/module-2-scanningbusiness-environment/m2- \%E2\%80\%93-week-4\%3A-analyse-the-institutional-environment (accessed on 23 November 2019).

87. Lienert, J.; SSWM (Sustainable Sanitation and Water Management Toolbox). Stakeholder Identification. 2019. Available online: https://sswm.info/planning-and-programming/exploring-tools/stakeholder-analysis/ stakeholder-identification (accessed on 15 October 2019). 
88. De Boer, M.A.; Romeo-Hall, A.; Rooimans, T.; Slootweg, J. An Assessment of the Drivers and Barriers for the Deployment of Urban Phosphorus Recovery Technologies: A Case Study of The Netherlands. Sustainability 2018, 10, 1790. [CrossRef]

89. McConville, J.R.; Künzle, R.; Messmer, U.; Udert, K.M.; Larsen, T.A. Decision Support for Redesigning Wastewater Treatment Technologies. Environ. Sci. Technol. 2014, 48, 12238-12246. [CrossRef]

90. Iwaniec, D.M.; Metson, G.S.; Cordell, D. P-Futures: Towards urban food \& water security through collaborative design and impact. Curr. Opin. Environ. Sustain. 2016, 20, 1-7. [CrossRef]

91. Harris-Lovett, S.; Lienert, J.; Sedlak, D. Towards a New Paradigm of Urban Water Infrastructure: Identifying Goals and Strategies to Support Multi-Benefit Municipal Wastewater Treatment. Water 2018, 10, 1127. [CrossRef]

92. Fang, L.L.; Valverde-Pérez, B.; Damgaard, A.; Plósz, B.G.; Rygaard, M. Life cycle assessment as development and decision support tool for wastewater resource recovery technology. Water Res. 2016, 88, 538-549. [CrossRef]

93. Andreoli, C.V.; Sperling, M.V.; Fernandes, F. Sludge Treatment and Disposal; IWA Publishing: London, UK, 2007.

94. Tarpani, R.R.Z.; Azapagic, A. Life cycle costs of advanced treatment techniques for wastewater reuse and resource recovery from sewage sludge. J. Clean. Prod. 2018, 204, 832-847. [CrossRef]

95. Bolzonella, D.; Battistoni, P.; Susini, C.; Cecchi, F. Anaerobic codigestion of waste activated sludge and OFMSW: The experiences of Viareggio and Treviso plants (Italy). Water Sci. Technol. 2006, 53, $203-211$. [CrossRef] [PubMed]

96. Matheri, A.N.; Ndiweni, S.N.; Belaid, M.; Muzenda, E.; Hubert, R. Optimising biogas production from anaerobic co-digestion of chicken manure and organic fraction of municipal solid waste. Renew. Sustain. Energy Rev. 2017, 80, 756-764. [CrossRef]

97. Brazil, National Secretary of Environmental Sanitation. Probiogás, 2015. Guia Técnico de Aproveitamento Energético de Biogás em Estações de Tratamento de Esgoto (Technical Guide for Energy Use of Biogas in Sewage Treatment Plants). Available online: https://www.giz.de/en/downloads/probiogas-guia-etes.pdf (accessed on 21 March 2020).

98. Bennamoun, L.; Arlabosse, P.; Léonard, A. Review on fundamental aspect of application of drying process to wastewater sludge. Renew. Sustain. Energy Rev. 2013, 28, 29-43. [CrossRef]

99. Li, Y.; Wang, H.; Zhang, J.; Wang, J.; Lan, O. Co-Processing Sewage Sludge in Cement Kiln in China. J. Water Resour. Prot. 2013, 05, 906-910. [CrossRef]

100. Pries, R.T.A. Uso do Lodo de Esgoto Para Coprocessamento em Fornos de Clínquer (Use of Sewage Sludge for Co-Processing in Clinker Kilns). Master's Thesis, University of Paraná, Curitiba, Parana, Brazil, 2018.

101. Nättorp, A.; Remmen, K.; Remy, C. Cost assessment of different routes for phosphorus recovery from wastewater using data from pilot and production plants. Water Sci. Technol. 2017, 76, 413-424. [CrossRef] [PubMed]

102. Desmidt, E.; Ghyselbrecht, K.; Zhang, Y.; Pinoy, L.; Van Der Bruggen, B.; Verstraete, W.; Rabaey, K.; Meesschaert, B. Global phosphorus scarcity and full-scale P-recovery techniques: A review. Crit. Rev. Environ. Sci. Technol. 2015, 45, 336-384. [CrossRef]

103. Egle, L.; Rechberger, H.; Krampe, J.; Zessner, M. Phosphorus recovery from municipal wastewater: An integrated comparative technological, environmental and economic assessment of P recovery technologies. Sci. Total Environ. 2016, 571, 522-542. [CrossRef]

104. Arvin, E.; Henze, M.; Harremöes, P. Wastewater Treatment Biological and Chemical Processes; Polyteknisk Forlag: Copenhagen, Denmark, 2019; ISBN 978-87-502-1150-1.

105. Münch, E.V.; Barr, K. Controlled struvite crystallisation for removing phosphorus from anaerobic digester sidestreams. Water Res. 2001, 35, 151-159. [CrossRef]

106. Zhou, K.; Barjenbruch, M.; Kabbe, C.; Inial, G.; Remy, C. Phosphorus recovery from municipal and fertilizer wastewater: China's potential and perspective. J. Environ. Sci. 2017, 52, 151-159. [CrossRef]

107. Xavier, L.D.; Cammarota, M.C.; Yokoyama, L.; Volschan, I. Study of the recovery of phosphorus from struvite precipitation in supernatant line from anaerobic digesters of sludge. Water Sci. Technol. 2014, 69, 1546-1551. [CrossRef] [PubMed]

108. Stratful, I.; Scrimshaw, M.D.; Lester, J.N. Removal of Struvite to Prevent Problems Associated with its Accumulation in Wastewater Treatment Works. Water Environ. Res. 2004, 76, 437-443. [CrossRef] [PubMed] 
109. Sikosana, M.; Randall, D.G.; Petrie, D.J.; Oelofse, M.; Russo, V.; Von Blottnitz, H. Nutrient and Energy Recovery from Sewage: Towards an Integrated Approach; WRC Report; Water Research Comission: Gezina, South Africa, 2016; ISBN 9781431207862.

110. Le Corre, K.S.; Valsami-Jones, E.; Hobbs, P.; Parsons, S.A. Phosphorus Recovery from Wastewater by Struvite Crystallization: A Review. Crit. Rev. Environ. Sci. Technol. 2009, 39, 433-477. [CrossRef]

111. Amann, A.; Zoboli, O.; Krampe, J.; Rechberger, H.; Zessner, M.; Egle, L. Environmental impacts of phosphorus recovery from municipal wastewater. Resour. Conserv. Recycl. 2018, 130, 127-139. [CrossRef]

112. Ye, Y.; Ngo, H.H.; Guo, W.; Chang, S.W.; Nguyen, D.D.; Zhang, X.; Zhang, J.; Liang, S. Nutrient recovery from wastewater: From technology to economy. Bioresour. Technol. Reports 2020, 100425. [CrossRef]

113. Shu, L.; Schneider, P.; Jegatheesan, V.; Johnson, J. An economic evaluation of phosphorus recovery as struvite from digester supernatant. Bioresour. Technol. 2006, 97, 2211-2216. [CrossRef]

114. Ahmed, M.; Chowdhury, H.; Rahman, H.; Uddin, S.A. Prospects of Using Wastewater as a Resource- Nutrient Recovery and Energy Generation Prospects of Using Wastewater as a Resource-Nutrient Recovery and Energy Generation. Am. J. Environ. Sci. 2015, 11, 99-114. [CrossRef]

115. Oyama, C. Nutrientes da Urina Humana Como Fertilizante Agrícola: Análise de Viabilidade Econômica Sobre um Modelo de Produção Baseado na Economia Solidária e na Agricultura Familiar (Nutrients of Human Urine as Agricultural Fertilizer: Economic Feasibility Analysis on a Production Model Based on Solidarity Economy and Family Agriculture). Master's Thesis, Technological Research Institute of the State of São Paulo, Sao Paulo, Brazil, 2013.

116. Bena-Filho, N.B. Estruvita: Identificação de Potenciais Perigos e Eventos Perigosos no Processo de Produção, Percepção e Aceitabilidade de Agricultores Quanto ao Seu Uso Agrícola (Struvite: Identification of Potential Hazards and Hazardous Events in the Production Process, Perception and Acceptability of Farmers Regarding Their Agricultural Use). Master's Thesis, Federal University of Espirito Santo, Vitoria, Brazil, 2019.

117. Lassen, J. Technologies in organic farming: Consumers? Values and acceptance. In Know Your Food; Wageningen Academic Publishers: Wageningen, The Netherlands, 2015; pp. 40-271. ISBN 978-90-8686-264-1.

118. Fytili, D.; Zabaniotou, A. Utilization of sewage sludge in EU application of old and new methods-A review. Renew. Sustain. Energy Rev. 2008, 12, 116-140. [CrossRef]

119. Tyagi, V.K.; Lo, S.-L. Sludge: A waste or renewable source for energy and resources recovery? Renew. Sustain. Energy Rev. 2013, 25, 708-728. [CrossRef]

120. Samolada, M.C.; Zabaniotou, A.A. Comparative assessment of municipal sewage sludge incineration, gasification and pyrolysis for a sustainable sludge-to-energy management in Greece. Waste Manag. 2014, 34, 411-420. [CrossRef]

121. Sabesp. Uso de Lodo de Esgoto na Agricultura-Estudo de Caso: Produzindo Fertilizantes na Estação de Tratamento de Franca (Use of Sewage Sludge in Agriculture-Case Study: Producing Fertilizers at the Franca Treatment Station). Available online: http://www.sabesp.com.br/Sabesp/filesmng.nsf/ DC466180BB9121BF8325760F006AEB08/\$File/uso_lodo_esgoto_agricultura.pdf (accessed on 15 March 2020).

122. Shiu, H.-Y.; Lee, M.; Chiueh, P.-T. Water reclamation and sludge recycling scenarios for sustainable resource management in a wastewater treatment plant in Kinmen islands, Taiwan. J. Clean. Prod. 2017, 152, 369-378. [CrossRef]

123. Souza, R.A.S.; González, M.D.M.; Santos, J.L.; Aparício, I.; Bissani, C.A.; Alonso, E. Metais pesados e compostos orgânicos tóxicos em lodo de esgoto e composto de lixo produzidos na cidade de Porto Alegre, RS (Heavy metals and toxic organic compounds from waste produced in Porto Alegre). In Proceedings of the XXXIII Congresso Brasileiro de Ciência do Solo, Uberlândia, Brazil, 31 July-5 August 2011.

124. Onwosi, C.O.; Igbokwe, V.C.; Odimba, J.N.; Eke, I.E.; Nwankwoala, M.O.; Iroh, I.N.; Ezeogu, L.I. Composting technology in waste stabilization: On the methods, challenges and future prospects. J. Environ. Manag. 2017, 190, 140-157. [CrossRef] [PubMed]

125. Visentin, R. Viabilidade econômica da compostagem de lodo de esgoto para fins agrícolas (Economic viability of composting sewage sludge for agricultural purposes). Master's Thesis, Paulista State University, Botucatu, Brazil, 2019.

126. Kacprzak, M.; Neczaj, E.; Fijałkowski, K.; Grobelak, A.; Grosser, A.; Worwag, M.; Rorat, A.; Brattebo, H.; Almås, Å.; Singh, B.R. Sewage sludge disposal strategies for sustainable development. Environ. Res. 2017, 156, 39-46. [CrossRef] [PubMed] 
127. Wei, Y.-S.; Fan, Y.-B.; Wang, M.-J. A cost analysis of sewage sludge composting for small and mid-scale municipal wastewater treatment plants. Resour. Conserv. Recycl. 2001, 33, 203-216. [CrossRef]

128. Oliveira, F.C. Compostagem de lodo (Sewage sludge composting). Tera Ambiental. Unpublished results. Sao Paulo, Brazil. Personal communication, 2020.

129. Delovitch, E.; Ringskog, K. Wastewater Treatment in Latin America: Old and New Options; The International Bank for Reconstruction and Development/The World Bank: Washington, DC, USA, 1997; Volume 1, ISBN 0821339699.

130. La Cour Jansen, J.; Gruvberger, C.; Hanner, N.; Aspegren, H.; Avärd, Å. Digestion of sludge and organic waste in the sustainability concept for Malmö, Sweden. Water Sci. Technol. 2004, 49, 163-169. [CrossRef]

131. CS Bioenergia. Bioenergia (Bioenergy). Available online: http://csbioenergia.com.br/bioenergia/\#processo (accessed on 15 April 2020).

132. Edelmann, W.; Engeli, H.; Gradenecker, M. Co-digestion of organic solid waste and sludge from sewage treatment. Water Sci. Technol. 2000, 41, 213-221. [CrossRef]

133. Doehler, H.; Eckel, H.; Froeba, N. Faustzahlen Biogas (Rule of thumb biogas). Darmstadt: Kuratorium Für Technik Und Bauwesen In der Landwirtschaft (Board of Trustees for Technology and Building in Agriculture). $2013 ; 360$.

134. Edwards, J.; Othman, M.; Crossin, E.; Burn, S. Anaerobic co-digestion of municipal food waste and sewage sludge: A comparative life cycle assessment in the context of a waste service provision. Bioresour. Technol. 2017, 223, 237-249. [CrossRef]

135. Brazil, National Secretary of Environmental Sanitation. Probiogás, 2016. Análise da Viabilidade Técnico-Econômica de Produção de Energia Elétrica em ETEs no Brasil a Partir do Biogás (Analysis of the Technical and Economic Feasibility of Producing Electricity in WWTPs in Brazil from Biogas). Available online: https://www.giz.de/en/downloads/Probiogas-EVTE-ETEs.pdf (accessed on 23 March 2020).

136. Wiese, J. Co-Digestion of Organic Waste on Wastewater Treatment Plants and Biogas Plants. In Proceedings of the Summer School on Wastewater and Biosolids Management, Patras, Greece, 22-27 July 2019; p. 35.

137. Forbes, R.; Fortin, A.; de Andrade, B.H.; Sa, L. Exploring the Feasibility of Water Resource and Recovery Facility (WRRF) Biogas Utilization in Brazil. Proc. Water Environ. Fed. 2018, 2018, 4090-4101. [CrossRef]

138. Felca, A.T.A.; Barros, R.M.; Tiago Filho, G.L.; dos Santos, I.F.S.; Ribeiro, E.M. Analysis of biogas produced by the anaerobic digestion of sludge generated at wastewater treatment plants in the South of Minas Gerais, Brazil as a potential energy source. Sustain. Cities Soc. 2018, 41, 139-153. [CrossRef]

139. Ornelas-Ferreira, B.; Lobato, L.C.S.; Colturato, L.F.D.; Torres, E.O.; Pombo, L.M.; Pujatti, F.J.P.; Araújo, J.C.; Chernicharo, C.A.L. Strategies for energy recovery and gains associated with the implementation of a solid state batch methanization system for treating organic waste from the city of Rio de Janeiro-Brazil. Renew. Energy 2020, 146, 1976-1983. [CrossRef]

140. Krupp, M.; Schubert, J.; Widmann, R. Feasibility study for co-digestion of sewage sludge with OFMSW on two wastewater treatment plants in Germany. Waste Manag. 2005, 25, 393-399. [CrossRef]

141. Syed-Hassan, S.S.A.; Wang, Y.; Hu, S.; Su, S.; Xiang, J. Thermochemical processing of sewage sludge to energy and fuel: Fundamentals, challenges and considerations. Renew. Sustain. Energy Rev. 2017, 80, 888-913. [CrossRef]

142. Associação Brasileira de Cimento Portland (ABCP, Brazilian Portland Cement Association). 2019. Panorama do Coprocessamento 2019-Ano Base 2017 (2019 Coprocessing Outlook-Base Year 2017). Available online: https://abcp.org.br/wp-content/uploads/2019/11/Panoramaco_processamento_2019_v2-bx.pdf (accessed on 11 March 2020).

143. AFNOR. Caracterisation des Boues- Bonne Pratique pour le Séchage des Boues; Technical Report FD X33-047; AFNOR: Paris, France, 2008.

144. Arlabosse, P.; Ferrasse, H.; Lecomte, D.; Crine, M.; Dumont, Y.; Léonard, A. Efficient Sludge Thermal Processing: From Drying to Thermal Valorization. In Modern Drying Technology; Wiley-VCH: Weinheim, Germany, 2012; Volume 4, pp. 295-329. ISBN 9783527631681.

145. Husillos Rodríguez, N.; Martínez-Ramírez, S.; Blanco-Varela, M.T.; Donatello, S.; Guillem, M.; Puig, J.; Fos, C.; Larrotcha, E.; Flores, J. The effect of using thermally dried sewage sludge as an alternative fuel on Portland cement clinker production. J. Clean. Prod. 2013, 52, 94-102. [CrossRef]

146. Nadal, M.; Schuhmacher, M.; Domingo, J.L. Cost-benefit analysis of using sewage sludge as alternative fuel in a cement plant: A case study. Environ. Sci. Pollut. Res. 2009, 16, 322-328. [CrossRef] [PubMed] 
147. Lv, D.; Zhu, T.; Liu, R.; Lv, Q.; Sun, Y.; Wang, H.; Liu, Y.; Zhang, F. Effects of co-processing sewage sludge in cement kiln on NO, NH3 and PAHs emissions. Chemosphere 2016, 159, 595-601. [CrossRef]

148. Xu, J.; Ping, L.; Cao, H.; Liu, W.; Gu, Y.; Lin, X.; Huang, J. Application status of co-processing municipal sewage sludge in cement kilns in China. Sustainability 2019, 11, 3315. [CrossRef]

149. Rulkens, W. Sewage sludge as a biomass resource for the production of energy: Overview and assessment of the various options. Energy Fuels 2008, 22, 9-15. [CrossRef]

150. Bertanza, G.; Baroni, P.; Canato, M. Ranking sewage sludge management strategies by means of Decision Support Systems: A case study. Resour. Conserv. Recycl. 2016, 110, 1-15. [CrossRef]

151. Zabaniotou, A.; Theofilou, C. Green energy at cement kiln in Cyprus-Use of sewage sludge as a conventional fuel substitute. Renew. Sustain. Energy Rev. 2008, 12, 531-541. [CrossRef]

152. Kääntee, U.; Zevenhoven, R.; Backman, R.; Hupa, M. Cement manufacturing using alternative fuels and the advantages of process modelling. Fuel Process. Technol. 2004, 85, 293-301. [CrossRef]

153. Cornel, P.; Schaum, C. Phosphorus recovery from wastewater: Needs, technologies and costs. Water Sci. Technol. 2009, 59, 1069-1076. [CrossRef]

154. Wong, P.Y.; Cheng, K.Y.; Kaksonen, A.H.; Sutton, D.C.; Ginige, M.P. A novel post denitrification configuration for phosphorus recovery using polyphosphate accumulating organisms. Water Res. 2013, 47, 6488-6495. [CrossRef] [PubMed]

155. Batista, J.R.; Jeong, H. Prediction of struvite formation potential in EBPR digested sludges. In Proceedings of the Water Environment Federation (WEFTEC 2006), Dallas, TX, USA, 22-25 October 2006; Volume 2006, pp. 5185-5196.

156. Kataki, S.; West, H.; Clarke, M.; Baruah, D.C. Phosphorus recovery as struvite from farm, municipal and industrial waste: Feedstock suitability, methods and pre-treatments. Waste Manag. 2016, 49, 437-454. [CrossRef] [PubMed]

157. Tomei, M.C.; Stazi, V.; Daneshgar, S.; Capodaglio, A.G. Holistic Approach to Phosphorus Recovery from Urban Wastewater: Enhanced Biological Removal Combined with Precipitation. Sustainability 2020, 12, 575. [CrossRef]

158. Moretti, S.M.L.; Bertoncini, E.I.; Vitti, A.C.; Alleoni, L.R.F.; Abreu-Junior, C.H. Concentration of Cu, Zn, $\mathrm{Cr}, \mathrm{Ni}, \mathrm{Cd}$, and $\mathrm{Pb}$ in soil, sugarcane leaf and juice: Residual effect of sewage sludge and organic compost application. Environ. Monit. Assess. 2016, 188, 163. [CrossRef] [PubMed]

159. Khadra, A.; Ezzariai, A.; Merlina, G.; Capdeville, M.-J.; Budzinski, H.; Hamdi, H.; Pinelli, E.; Hafidi, M. Fate of antibiotics present in a primary sludge of WWTP during their co-composting with palm wastes. Waste Manag. 2019, 84, 13-19. [CrossRef] [PubMed]

160. Di Maria, F.; Sordi, A.; Cirulli, G.; Micale, C. Amount of energy recoverable from an existing sludge digester with the co-digestion with fruit and vegetable waste at reduced retention time. Appl. Energy 2015, 150, 9-14. [CrossRef]

161. Di Maria, F.; Sordi, A.; Cirulli, G.; Gigliotti, G.; Massaccesi, L.; Cucina, M. Co-treatment of fruit and vegetable waste in sludge digesters. An analysis of the relationship among bio-methane generation, process stability and digestate phytotoxicity. Waste Manag. 2014, 34, 1603-1608. [CrossRef]

162. Rouhollahi, Z.; Ebrahimi-Nik, M.; Ebrahimi, S.H.; Abbaspour-Fard, M.H.; Zeynali, R.; Bayati, M.R. Farm biogas plants, a sustainable waste to energy and bio-fertilizer opportunity for Iran. J. Clean. Prod. 2020, 253, 119876. [CrossRef]

163. Uusitalo, A.; Uusitalo, V.; Grönman, A.; Luoranen, M.; Jaatinen-Värri, A. Greenhouse gas reduction potential by producing electricity from biogas engine waste heat using organic Rankine cycle. J. Clean. Prod. 2016, 127, 399-405. [CrossRef]

164. Visedo, G.; Marcelo, P.C. Roadmap Tecnológico do Cimento: Potencial de Redução das Emissões de Carbono da Indústria do Cimento Brasileira Até 2050 (Technological Cement Roadmap: Potential to Reduce Emissions Carbon Emissions from the Brazilian Cement Industry by 2050). Available online: http://snic.org.br/noticias-ver.php?id=28 (accessed on 3 December 2019).

165. United Nations Environment Programme (UNEP). Technical guidelines on the environmentally sound co processing of hazardous wastes in cement kilns. In Proceedings of the Conference of the Parties to the Basel Convention on the Control of Transboundary Movements of Hazardous Wastes and Their Disposal Tenth meeting, Cartagena, Colombia, 17-21 October 2011. 
166. CETESB (Environmental Agency of the State of Sao Paulo). Estudo de Baixo Carbono Para a Indústria de Cimento no Estado de São Paulo de 2014 a 2030 (Low Carbon Study for the Cement Industry in the State of São Paulo from 2014 to 2030). 2018. Available online: URLhttps:/cetesb.sp.gov.br/proclima/wp-content/uploads/sites/36/2018/09/ CIMENTO-PUBLICA\%C3\%87\%C3\%83O_on-line.pdf (accessed on 30 November 2020).

167. Saad, D.; Byrne, D.; Drechsel, P. Social perspectives on the effective management of wastewater. In Physico-Chemical Wastewater Treatment and Resource Recovery; InTech: London, UK, 2017; pp. 253-267.

168. Martins, E.S.C.S. Efeito do Armazenamento Sobre as Características de Urina e Águas Amarelas (Effect of Storage on Urine and Yellow Water Characteristics). Master's Thesis, State University of Paraiba, Campina Grande, Brazil, 2016.

169. Delanka-Pedige, H.M.K.; Munasinghe-Arachchige, S.P.; Abeysiriwardana-Arachchige, I.S.A.; Nirmalakhandan, N. Wastewater infrastructure for sustainable cities: Assessment based on UN sustainable development goals (SDGs). Int. J. Sustain. Dev. World Ecol. 2020, 1-7. [CrossRef]

170. Aguasan. Circular Economy -Transforming Waste into Resources: From Linear to Circular Water and Sanitation Models; Swiss Agency ford Development and Cooperation: Spiez, Switzerland, 2017; pp. 1-6.

171. Kurian, M. The water-energy-food nexus. Environ. Sci. Policy 2017, 68, 97-106. [CrossRef]

172. Andersson, K.; Otoo, M.; Nolasco, M. Innovative sanitation approaches could address multiple development challenges. Water Sci. Technol. 2018, 77, 855-858. [CrossRef] [PubMed]

173. Marttunen, M.; Mustajoki, J.; Sojamo, S.; Ahopelto, L.; Keskinen, M. A Framework for Assessing Water Security and the Water-Energy-Food Nexus-The Case of Finland. Sustainability 2019, 11, 2900. [CrossRef]

174. Ramôa, A.R.; McConville, J.; Lüthi, C.; Matos, J.S. Use of process guides for comprehensive urban sanitation technology decision-making: Practice versus theory. Water Policy 2018, 20, 158-174. [CrossRef]

175. Allesch, A.; Brunner, P.H. Material Flow Analysis as a Decision Support Tool for Waste Management: A Literature Review. J. Ind. Ecol. 2015, 19, 753-764. [CrossRef]

176. Yiougo, L.S.A.; Spuhler, D. SSWM (Sustainable Sanitation and Water Management Toolbox). Stakeholder Identification. Available online: https://sswm.info/ar/sswm-university-course/module-4-sustainable-water-supply/ further-resources-water-sources-software/material-flow-analysis- $\% 28 \mathrm{mfa} \% 29$ (accessed on 5 May 2018).

177. Krause, A.; Rotter, V.S. Linking energy-sanitation-agriculture: Intersectional resource management in smallholder households in Tanzania. Sci. Total Environ. 2017, 590-591, 514-530. [CrossRef]

178. Brazil. Resolução $n^{\circ}$ 687. (Joint Resolution No. 687). Brazil. 2015. Available online: https://microinversor. com.br/resolucao-normativa-687-aneel/?v=9a5a5f39f4c7 (accessed on 7 July 2020).

179. MAPA (Ministério da Agricultura, Pecuária e Abastecimento or Ministry of Agriculture, Livestock and Supply). 2006. Instrução Normativa SDA n² 27. (Normative Instruction N. 27). Brazil. Available online: https://www.legisweb.com.br/legislacao/?id=76854 (accessed on 20 January 2020).

180. MAPA (Ministério da Agricultura, Pecuária e Abastecimento or Ministry of Agriculture, Livestock and Supply). 2009. Instrução Normativa SDA/MAPA $\mathrm{n}^{\circ}$ 25. (Normative Instruction N. 25). Brazil. Available online: http://sistemasweb.agricultura.gov.br/sislegis/action/detalhaAto.do?method= recuperarTextoAtoTematicaPortal\&codigoTematica=1229186 (accessed on 20 January 2020).

181. MAPA (Ministério da Agricultura, Pecuária e Abastecimento or Ministry of Agriculture, Livestock and Supply). 2016. Instrução Normativa SDA n 7. (Normative Instruction No. 7). Brazil. Available online: https://www.lex.com.br/legis_27129277_INSTRUCAO_NORMATIVA_N_7_DE_12_DE_ ABRIL_DE_2016.aspx (accessed on 24 January 2020).

182. Ministry of the Environment. Resolução ${ }^{\circ}$ 153. (Joint Resolution No. 153). Brazil. 2013. Available online: http://www.cnrh.gov.br/aguas-subterraneas/1715-resolucao-153-recarga/file (accessed on 30 March 2019).

183. Miranda-Sampaio, L. Tendências recentes da espacialização das indústrias e serviços em São Paulo e no ABC paulista (Recent trends in the spatial distribution of industries and services in São Paulo and ABC paulista). Econ. Soc. Territ. 2015, 15, 483-515.

184. National Agency for Petroleum, Natural Gas and Biofuels. Resolução $n^{\circ} 685$ (Joint Resolution No. 685). Brazil. 2017. Available online: http://legislacao.anp.gov.br/?path=legislacao-anp/resol-anp/2017/junho\& item=ranp-685--2017 (accessed on 10 March 2019).

185. National Water Agency (ANA). Resolução n 744. (Joint Resolution No. 744). Brazil. 2017. Available online: http://arquivos.ana.gov.br/resolucoes/2017/744-2017.pdf. (accessed on 10 April 2019). 
186. Página Rural (Rural Page). SP: Agricultura Resiste no Grande ABC (SP: Agriculture Resists in Greater ABC) 2005. Available online: http://www.paginarural.com.br/noticia/24485/sp-agricultura-resiste-no-grande-abc (accessed on 10 March 2019).

187. Rostichelli, M. Entre a Terra e o Asfalto: A região Metropolitana de São Paulo no contexto da Agricultura Urbana (Between Earth and Asphalt: The Metropolitan Region of São Paulo in the context of Urban Agriculture). Master's Thesis, in Geography. University of Sao Paulo, São Paulo, 2013.

188. Sao Caetano do Sul City. Lei $n^{\circ} 5.316$ (Law No. 5316). Brazil. 2015. Available online: https://leismunicipais.com.br/a/sp/s/sao-caetano-do-sul/lei-ordinaria/2015/531/5316/lei-ordinaria-n-53162015-aprova-o-plano-municipal-de-educacao-e-da-outras-providencias (accessed on 2 June 2019).

189. Sao Paulo City. Lei $n^{\circ} 16.174$ (Law No. 16174). Brazil. 2015. Available online: https://www.legisweb.com.br/ legislacao/?id=283663 (accessed on 15 February 2020).

190. Sao Paulo State Government. Decreto $n^{\circ} 58.107$ (Decree No. 58107). Brazil. 2012. Available online: https: //www.al.sp.gov.br/repositorio/legislacao/decreto/2012/decreto-58107-05.06.2012.html (accessed on 5 May 2019).

191. Sao Paulo State Water and Sewage Services Company (SABESP) Sustainability Report 2018. Available online: http://site.sabesp.com.br/site/uploads/file/relatorios_sustentabilidade/sabesp_rs_2018_ portugues.pdf (accessed on 6 July 2019).

192. Tchobanoglous, G.; Stensel, H.D.; Tsuchihashi, R.; Burton, F.; Abu-Orf, M.; Bowden, G.; Pfrang, W. Metcalf E Eddy/AECOM: Tratamento de Efluentes e Recuperação de Recursos (Wastewater Treatment and Resource Recovery), 5th ed.; AMGH Editora Ltd.: Porto Alegre, Brazil, 2015; p. 2008.

193. Brazil (National Environment Council-CONAMA). Resolution Number 499 of National Environment Council of 6 October 2020. Licenciamento de co-processamento de resíduos em fornos rotativos de produção de clínquer (Licensing of co-processing of waste in rotary kilns for clinker production). Available online: https://www.in.gov.br/en/web/dou/-/resolucao-conama/mma-n-499-de-6-de-outubro-de2020-281790575 (accessed on 1 November 2020).

194. Brazil Resolution number 316 of National Environment Council (CONAMA) of 29 October 2002. Dispõe Sobre Procedimentos e Critérios Para o Funcionamento de Sistemas de Tratamento Térmico de Resíduos (Provides for Procedures and Criteria for the Operation of Thermal Waste Treatment Systems). Available online: https://www.legisweb.com.br/legislacao/?id=98287 (accessed on 2 October 2019).

195. Brazil Resolution number 436 of National Environment Council of 22 December 2011. Estabelece os Limites Máximos de Emissão de Poluentes Atmosféricos Para Fontes Fixas Instaladas ou Com Pedido de Licença de Instalação Anteriores a 02 de Janeiro de 2007 (Establishes Maximum limits for Emissions of Atmospheric Pollutants). Available online: https://www.normasbrasil.com.br/norma/resolucao-436-2011_114141.html (accessed on 20 January 2020).

196. Cao, H.; Liu, J.; Xu, J.; Liu, W.; Huang, X.; Li, G. The Property of Lime Sewage Sludge and its Influence on Co-Processing in Cement Kilns. Pol. J. Environ. Stud. 2016, 25, 959-971. [CrossRef]

197. CETESB (Environmental Agency of the State of Sao Paulo). Norma Técnica $n^{\circ}$ P4. 263, de Dezembro de 2003 (Technical Standard No. P4. 263 of December 2003). Procedimento para Utilização de Resíduos em Fornos de Produção de Clínquer (Procedure for Using Wastes in Kilns for Clinker Production). 2003. Available online: https://cetesb.sp.gov.br/camaras-ambientais/wp-content/uploads/sites/21/2013/12/P4_263.pdf (accessed on 4 December 2020).

198. Favaro Junior, D. Co-Processamento de Resíduos Industriais em Fornos de Clínquer (Co-Processing of Industrial Waste in Clinker Kilns); Cia de Cimento Itambé: Balsa Nova, Brazil, 2018.

199. Hannoun, G. Energetic potential and environmental assessment of solid wastes as alternative fuel for cement plants. Appl. Ecol. Environ. Res. 2019, 17, 15151-15168. [CrossRef]

200. Kim, H.-W.; Han, S.-K.; Shin, H.-S. The optimisation of food waste addition as a co-substrate in anaerobic digestion of sewage sludge. Waste Manag. Res. 2003, 21, 515-526. [CrossRef] [PubMed]

201. Leite, T.A. Compostagem termofílica de lodo de esgoto: Higienização e produção de biossólido para uso agrícola (Thermophilic composting of sewage sludge: Cleaning and production of biosolids for agricultural use). Master's Thesis, University of Sao Paulo, São Paulo, Brazil, 2015.

202. Leite, V.D.; Barros, A.J.M.; Menezes, J.M.C.; de Sousa, J.T.; Lopes, W.S. Codigestão anaeróbia de resíduos orgânicos. Rev. DAE 2017, 65, 35-46. [CrossRef]

203. Modaresi, Z.K.; Karimi, G.; Mowla, D. Study of co-combustion of dried sewage sludge with coke: Thermogravimetric assessment and gaseous emissions. J. Environ. Chem. Eng. 2019, 7, 102871. [CrossRef] 
204. Rahman, A.; Rasul, M.G.; Khan, M.M.K.; Sharma, S. Recent development on the uses of alternative fuels in cement manufacturing process. Fuel 2015, 145, 84-99. [CrossRef]

205. Rizk, M.C.; Bergamasco, R.; Tavares, C.R.G. Anaerobic Co-digestion of Fruit and Vegetable Waste and Sewage Sludge. Int. J. Chem. React. Eng. 2007, 5. [CrossRef]

206. Sao Paulo (State). Resolution of Secretary of the Environment N. 38 of May 31, 2017; Secretary of Environment of the State of Sao Paulo: Sao Paulo, Brazil, 2017.

207. Sosnowski, P.; Klepacz-Smolka, A.; Kaczorek, K.; Ledakowicz, S. Kinetic investigations of methane co-fermentation of sewage sludge and organic fraction of municipal solid wastes. Bioresour. Technol. 2008, 99, 5731-5737. [CrossRef]

208. Udaeta, M.E.M.; Medeiros, G.A.; da Silva, V.O.; Galvão, L.C.R. Basic and procedural requirements for energy potential from biogas of sewage treatment plants. J. Environ. Manag. 2019, 236, 380-387. [CrossRef]

209. Flaga, A. The Aspects of Sludge Thermal Utilization. Available online: https://pdfs.semanticscholar.org/18ce/ db07850fd28afc5695ed1f8497a1c6687355.pdf (accessed on 9 February 2020).

210. CSBio. Bioenergia (Bioenergy). 2019. Available online: http://csbioenergia.com.br/portfolio/videos/ (accessed on 30 November 2020).

Publisher's Note: MDPI stays neutral with regard to jurisdictional claims in published maps and institutional affiliations.

(C) 2020 by the authors. Licensee MDPI, Basel, Switzerland. This article is an open access article distributed under the terms and conditions of the Creative Commons Attribution (CC BY) license (http://creativecommons.org/licenses/by/4.0/). 